\title{
FLUCTUATION OF ION COMPONENTS, TRACE METALS, AND Pb/Zn RATIO IN PRECIPITATION AT TSU CITY
}

\author{
Makiko SENDA 1, 2, 3, Tadashi NISHI ${ }^{4}$, Naoko TAKAGI ${ }^{5}$, Fuki SUGIYAMA 6 \\ and Yasuhisa KUZUHA ${ }^{7}$
}

\author{
${ }^{1}$ Member of JSCE, Lecturer, Faculty of Health Science, Kyoto Koka Women's University \\ and Kyoto Koka Women's College (38, Nishikyougokukadono-cho, Ukyo-ku, Kyoto City, Kyoto 615-0882, Japan) \\ E-mail: m-senda@mail.koka.ac.jp \\ ${ }^{2}$ Lecturer, Faculty of Management, Osaka Seikei University and Osaka Seikei College \\ (3-10-62, Aikawa, Higashiyodogawa-ku, Osaka City, Osaka 533-0007, Japan) \\ E-mail: senda@osaka-seikei.ac.jp \\ ${ }^{3}$ Lecturer, Faculty of Human Development and Education, Kobe Shinwa Women's University \\ (7-13-1, Suzurandaikitamachi, Kita-ku, Kobe City, Hyogo 651-1111, Japan) \\ ${ }^{4}$ Nonmember of JSCE, Graduate student, Graduate School of Bioresources, Mie University \\ (1577 Kurimamachiya-cho, Tsu City, Mie 514-8507, Japan) \\ E-mail: 513m229@m.mie-u.ac.jp \\ ${ }^{5}$ Nonmember of JSCE, Faculty of Bioresources, Mie University \\ (1577 Kurimamachiya-cho, Tsu City, Mie 514-8507, Japan) \\ ${ }^{6}$ Nonmember of JSCE, Faculty of Bioresources, Mie University \\ (1577 Kurimamachiya-cho, Tsu City, Mie 514-8507, Japan) \\ ${ }^{7}$ Fellow of JSCE, Professor, Graduate School of Bioresources, Mie University \\ (1577 Kurimamachiya-cho, Tsu City, Mie 514-8507, Japan) \\ E-mail: kuzuha@bio.mie-u.ac.jp
}

To elucidate the air pollution, its features, its sources, and the influence of yellow sand (kosa) in Tsu City, the ion components and trace metals in precipitation at Mie University were measured along with their temporal changes. From the obtained correlation coefficients and the results of the principal component analysis, the ions and the trace metals in the precipitation were classified into three groups: the SSI group (the ions of $\mathrm{Cl}^{-}, \mathrm{Na}^{+}, \mathrm{K}^{+}, \mathrm{Mg}^{2+}$, ss- $\mathrm{SO}_{4}{ }^{2-}$ and $\mathrm{ss}-\mathrm{Ca}^{2+}$, of which the main sources were sea salt); the ASI group (the ions of $\mathrm{F}^{-}, \mathrm{NO}_{3}{ }^{-}, \mathrm{NH}_{4}{ }^{+}$, nss- $\mathrm{SO}_{4}{ }^{2-}$ and nss-Ca ${ }^{2+}$, of which the main sources were anthropogenic pollution and soil); and the ASM group (trace metals of $\mathrm{Al}, \mathrm{Fe}, \mathrm{Mn}, \mathrm{Pb}$, and $\mathrm{Zn}$, of which the main sources were anthropogenic pollution and soil). The concentrations of the SSI group tended to be higher with increased wind velocity. Results suggest that seawater was raised into the atmosphere in proportion to the wind velocity, and that the sea salt ions were transported and increased in the precipitation. The effects of long-range transport and local pollution on the pollutants and the soil elements in the precipitation were discussed from measurements of the concentration ratios of $\mathrm{Pb}$ and $\mathrm{Zn}(\mathrm{Pb} / \mathrm{Zn})$ and backward trajectory analysis. The concentrations of ion components and trace metals during the rain events in Tsu City, Mie generally decreased over time. The condensed pollutants in the air are regarded as removed in the initial period of the rain events. We can confirm that the concentration ratios ( $\mathrm{Pb} / \mathrm{Zn}$ ratios) are almost identical to reported values for rain clouds through Japan. Only one day showed high rates of pollutants, but it is presumed to be not the effect of kosa but of the industrial zone to the north east of Tsu City.

Key Words : precipitation, trace metals, ion components, Pb/Zn Ratio, wash-out, rain-out

\section{INTRODUCTION}

Recently, various environmental problems have become important global social issues. Severe air pollution in China has raised concerns related to the increase of transboundary air pollution and acid rain in Japan. The combination of yellow sand (kosa) and air pollutants, their transformation, and photochem- 
Table 1 Pollution process of precipitation ${ }^{7), 8), 9), ~ 10) . ~}$

\begin{tabular}{l|l|l}
\hline & \multicolumn{1}{|c|}{ Transport of pollutants } & \multicolumn{1}{c}{ Local emission } \\
\hline Main process & $\begin{array}{l}\text { Rain-out : Rain clouds catch atmos- } \\
\text { pheric pollutants during their move- } \\
\text { ment. }\end{array}$ & $\begin{array}{l}\bullet \text { Accumulation } \\
\text { Wash-out : Raindrops catch atmospheric } \\
\text { pollutants. }\end{array}$ \\
\hline Pollutants & $\begin{array}{l}\text { Trace metals insoluble in water. } \\
\text { Exhaust gas of cars, boilers, steel industries, } \\
\text { waste combustion facilities, etc. }\end{array}$ & $\begin{array}{l}\text { Nitrogen oxides and sulfur oxides which are } \\
\text { soluble in water. } \\
\text { Exhaust gas of cars, smoke of factories, vol- } \\
\text { canic ashes, etc. }\end{array}$ \\
\hline
\end{tabular}

ical pollution have been observed. Therefore, it is important to clarify the pollutants' influence on the environment ${ }^{1)}$. Acid rain, which results from artificial pollutants released into the atmosphere, has influenced precipitation water quality in recent years. It has been regarded as a global environmental destruction problem ${ }^{2}$. The acidification substances of $\mathrm{NO}_{3}{ }^{-}$and $\mathrm{SO}_{4}{ }^{2-}$ are known to be generated from nitrogen oxide and sulfur oxide emitted by the combustion of fossil fuels.

Studies of acid rain in Europe and the United States show that the acidification of precipitation in the United States spread from the northeast region to the west region and the south region from 1956 through 1976. Moreover, acidity in the northeast region had increased ${ }^{3)}$.

Ezcurra et $a l .{ }^{4)}$ reported the precipitation water quality of 52 rain events in 1986 in Basque Provinces in Spain. The study showed that the pressure pattern and the atmospheric air inflow at the precipitation influenced the precipitation water quality. The concentrations of $\mathrm{NO}_{3}{ }_{3}^{-}, \mathrm{SO}_{4}{ }^{2-}$ and $\mathrm{NH}_{4}{ }^{+}$were high with highly acid precipitation, which pointed out that acidification was highly influenced by industrial areas in the south of France and the north of Spain. Regarding acid rain in Japan, harm to the human body such as eye irritation from rain drizzle, was reported in Shizuoka and Yamanashi prefectures in $1973^{5)}$. That study triggered acid rain studies in Japan.

The causes of the precipitation pollution are regarded as divisible into natural and artificial factors according to their generation processes and forms. Coarse particles with diameter greater than about 2.5 $\mu \mathrm{m}$ originate mainly from soil, sea salt, and so forth. Smaller microparticles are produced by waste incineration facilities, automobile exhaust gas, and so on ${ }^{6}$.

The pollution process of the precipitation water is classified into the transport of pollutants (rain-out) and the local emissions (accumulation, wash-out), as shown in Table $\mathbf{1}^{7)-10)}$.

As indicators of the long-range transport of the air pollutants, the concentration ratios of metal elements are adopted and the ratio of $\mathrm{Pb}$ and $\mathrm{Zn}(\mathrm{Pb} / \mathrm{Zn})$ is considered effective, particularly because they have not been strongly influenced by meteorological conditions ${ }^{11)}$. Hioki et al. ${ }^{8)}$ showed that the ratio of $\mathrm{Pb} / \mathrm{Zn}$ tended to shift upward under the influence of the long-range transport from the Asian Continent, and reported that this ratio was an effective index for pollution by both the long-range transport (rain-out) and local emissions (wash-out). To examine whether the trace metal concentrations are an effective index for air pollution by long-range transport, Okuda et al. ${ }^{12)}$ measured the concentrations at Rishiri Island, located in northernmost Japan and easternmost from the Asian continent. The measured concentration ratios of $\mathrm{Pb}$ and $\mathrm{Zn}$ and the backward trajectory analysis with the four divided areas of the sea, Japan, China, and Siberia showed that the ratios varied according to their source areas. The effect of the long-range transport is regarded as indicated by the ratio of highly correlated trace metals with the same sources. Salient results of some studies of the $\mathrm{Pb}$ and $\mathrm{Zn}$ ratio are presented in Table $\mathbf{2}^{8), 11)-22 \text { ). }}$

In this study, to assess air pollution, its features, its sources, and its influence of kosa on Tsu City, the ion components and the trace metals in the precipitation and their temporal changes were measured at Mie University. Then the effects of long-range transport and local pollutants and the soil elements are explained based on the $\mathrm{Pb}$ and $\mathrm{Zn}(\mathrm{Pb} / \mathrm{Zn})$ concentration ratio and backward trajectory analysis.

\section{MATERIALS AND METHODS}

\section{(1) Study area}

Tsu City (Fig.1) in Mie prefecture is surrounded by Ise Bay on the east, by mountains on the west, and by urban areas to the north and south. Fig.1 shows that the industrial zones of the cities of Yokkaich and Suzuka are located on the north of Tsu City. From the north to the east across Ise Bay, there are the Indus trial zones of the cities of Nagoya, Toyota, Toyohashi, and Okazaki. Iron and steel factories ${ }^{23)}$, automotive factories ${ }^{24)}$, thermal power plants ${ }^{25)}$, petrochemical complexes ${ }^{26}$, refuse incineration facile- 
Table $2 \mathrm{~Pb} / \mathrm{Zn}$ ratio in precipitation and aerosols.

\begin{tabular}{|c|c|c|c|c|c|c|c|c|c|}
\hline \multirow{2}{*}{ Year } & \multirow{2}{*}{ Sample } & \multicolumn{2}{|l|}{ Sampling area } & \multirow{2}{*}{$\begin{array}{l}\text { Aerosols } \\
\text { in China }\end{array}$} & \multirow{2}{*}{$\begin{array}{l}\text { Aerosols } \\
\text { in Japan }\end{array}$} & \multirow{2}{*}{$\begin{array}{l}\text { Through } \\
\text { Japan }\end{array}$} & \multirow{2}{*}{$\begin{array}{l}\text { Through } \\
\text { Central } \\
\text { China, } \\
\text { Korea }\end{array}$} & \multirow{2}{*}{$\begin{array}{c}\text { Through } \\
\text { North } \\
\text { China, } \\
\text { Far east } \\
\text { Russia } \\
\end{array}$} & \multirow{2}{*}{ Sources } \\
\hline & & Japan & China & & & & & & \\
\hline $\begin{array}{l}1974 \\
-1977 \\
\end{array}$ & $\begin{array}{l}\text { Atmospheric } \\
\text { aerosols }\end{array}$ & $\begin{array}{l}\text { Sakai City, } \\
\text { Osaka } \\
\end{array}$ & - & - & 0.62 & - & - & - & $\begin{array}{l}\text { Mizohata \& } \\
\text { Mamuro, } 1980^{15)} \\
\end{array}$ \\
\hline $\begin{array}{l}1985 \\
-1991\end{array}$ & $\begin{array}{l}\text { Total } \\
\text { Suspended } \\
\text { Particles } \\
\text { (TSP) }\end{array}$ & $\begin{array}{l}\text { Oki island, } \\
\text { Shimane }\end{array}$ & - & - & - & 0.5 & 1 & 0.6 & $\begin{array}{l}\text { Mukai et al., } \\
1990^{16)}, 1994^{17)}\end{array}$ \\
\hline $\begin{array}{l}1990 \\
-1992 \\
\end{array}$ & Snow & $\begin{array}{l}\text { National parks } \\
\text { ( } 24 \text { points) }\end{array}$ & - & - & - & 0.36 & $0.7 \sim 1.32$ & - & Mukai et al., 19998) \\
\hline $\begin{array}{l}1995 \\
-1996\end{array}$ & $\begin{array}{l}\text { Total } \\
\text { Suspended } \\
\text { Particles } \\
\text { (TSP) }\end{array}$ & \begin{tabular}{|l} 
National \\
atmosphere \\
measurement \\
station \\
(16 points) \\
\end{tabular} & - & - & 0.34 & - & - & - & $\begin{array}{l}\text { The Environmental } \\
\text { Administration } \\
\text { Bureau, } 1996^{22)}\end{array}$ \\
\hline $\begin{array}{l}1995 \\
-2004 \\
\end{array}$ & $\begin{array}{l}\text { Atmospheric } \\
\text { aerosols }\end{array}$ & Tokyo & - & - & 0.28 & - & - & - & \begin{tabular}{|l} 
Furuta et al., \\
$2005^{13)}$
\end{tabular} \\
\hline $\begin{array}{l}1998 \\
-2000\end{array}$ & \begin{tabular}{|l} 
Total \\
Suspended \\
Particles \\
(TSP) \\
\end{tabular} & $\begin{array}{l}\text { Matsue City, } \\
\text { Shimane }\end{array}$ & - & - & - & 0.21 & 0.55 & - & $\begin{array}{l}\text { Marumoto et al., } \\
2001^{14)}\end{array}$ \\
\hline $\begin{array}{l}2000 \\
-2001 \\
\end{array}$ & Rainwater & $\begin{array}{l}\text { Komae City, } \\
\text { Tokyo }\end{array}$ & - & - & - & $0.2 \sim 0.3$ & - & - & $\begin{array}{l}\text { Sakata \& } \\
\text { Marumoto, 2004 }{ }^{20)}\end{array}$ \\
\hline $\begin{array}{l}2001 \\
-2002 \\
\end{array}$ & $\begin{array}{l}\text { PM2.5 } \\
\quad+\text { PM10-2.5 } \\
\end{array}$ & $\begin{array}{l}\text { Tango peninsula, } \\
\text { Kyoto }\end{array}$ & - & - & - & 0.26 & 0.65 & - & $\begin{array}{l}\text { Hioki et al., } \\
2008^{8)}\end{array}$ \\
\hline $\begin{array}{l}2001 \\
-2003 \\
\end{array}$ & Aerosol & $\begin{array}{l}\text { Rishiri island, } \\
\text { Hokkaido }\end{array}$ & - & - & - & 0.7 & 2.8 & 2.6 & $\begin{array}{l}\text { Okuda et al., } \\
2006^{12)}\end{array}$ \\
\hline $\begin{array}{l}2001 \\
-2003 \\
\end{array}$ & Aerosol & - & \begin{tabular}{|l|} 
Beijing \\
City
\end{tabular} & 0.56 & - & - & - & - & $\begin{array}{l}\text { Okuda et al, } \\
2004^{19)}\end{array}$ \\
\hline $\begin{array}{l}2007 \\
-2008\end{array}$ & Rainwater & $\begin{array}{l}\text { Fukuoka City, } \\
\text { Fukuoka }\end{array}$ & - & - & - & 0.26 & 0.50 & 0.23 & $\begin{array}{l}\text { Shimada et al, } \\
2008^{21)}\end{array}$ \\
\hline 2007 & $\begin{array}{l}\text { Total } \\
\text { Suspended } \\
\text { Particles } \\
\text { (TSP) } \\
\end{array}$ & $\begin{array}{l}\text { Matsuyama City } \\
\text { Osaka City } \\
\text { Tsukuba City }\end{array}$ & - & - & $\begin{array}{l}0.28 \\
0.18 \\
0.16\end{array}$ & - & $\begin{array}{c}0.62 \\
0.31 \\
-\end{array}$ & - & $\begin{array}{l}\text { Hioki et al., } \\
2009^{11)}\end{array}$ \\
\hline
\end{tabular}

Precipitation is indicated in bold italic type.

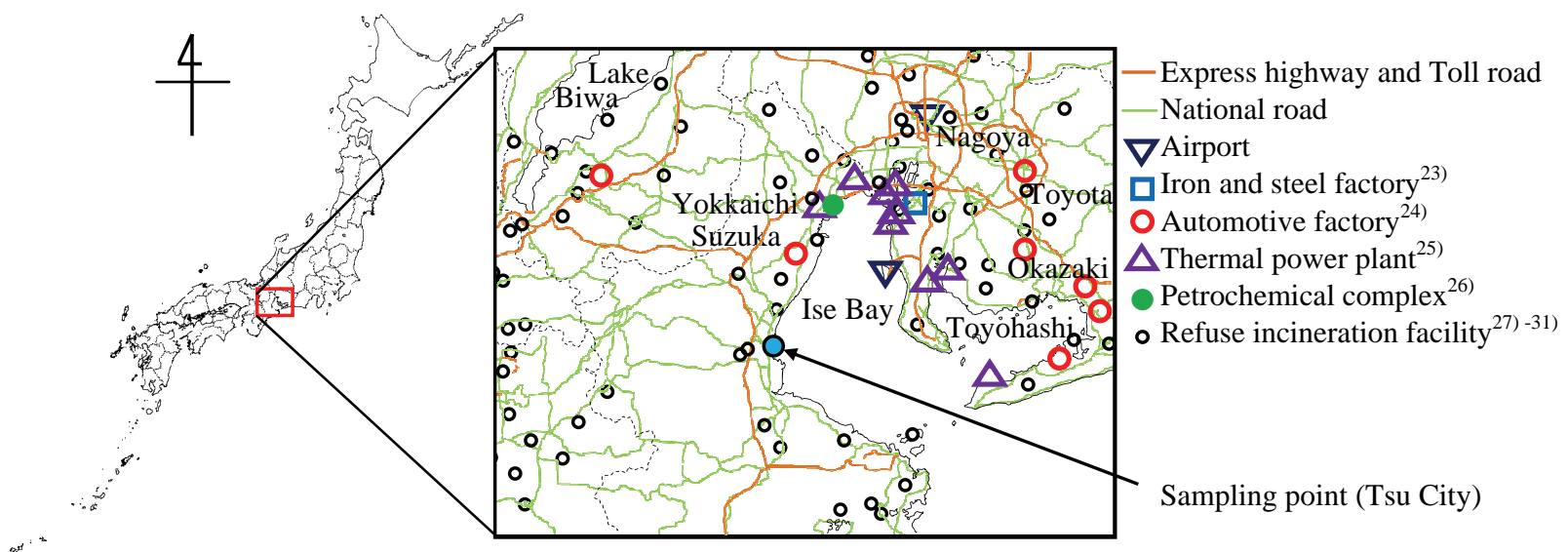

Fig.1 Sampling sites for rain water. 
ties $^{27)-31)}$, and airports are in these zones.

Mie University in Tsu City is in similar environment conditions. It faces Ise Bay on the east. On the west, National Highway Route 23 and Ise Expressway run between the university and the mountains. The chemical components generated in those regions are regarded as included among those present in the precipitation.

\section{(2) Sampling methods and analyses}

After 14 events of the preliminary observations of the rainwater from August 2010 through January 2011, 31 rain events from August 2011 through December 2012 were performed with funnels and polyethylene bags at the roof terrace of Mie University (Fig.1). The containers were installed with no obstacles within 30 degrees vertically around them. The collected rainwater was stored in a refrigerator.

$\mathrm{F}^{-}, \mathrm{Cl}^{-}, \mathrm{NO}_{2}^{-}, \mathrm{Br}^{-}, \mathrm{NO}_{3}{ }^{-}, \mathrm{PO}_{4}{ }^{3-}, \mathrm{SO}_{4}{ }^{2-}, \mathrm{Li}^{+}, \mathrm{Na}^{+}$, $\mathrm{NH}_{4}^{+}, \mathrm{K}^{+}, \mathrm{Mg}^{2+}$, and $\mathrm{Ca}^{2+}$ were analyzed using ion chromatography (Prominence HIC-SP/NS; Shimadzu Corp., Japan), with anion analysis using suppressor method (column: Shim-Pack IC-SA2), and with positive ion analysis conducted using the non-suppressor method (column: Shim-Pack IC-C4).

$\mathrm{Al}, \mathrm{Ba}, \mathrm{Cd}, \mathrm{Cr}, \mathrm{Cu}, \mathrm{Fe}, \mathrm{Li}, \mathrm{Mn}, \mathrm{Ni}, \mathrm{Pb}$, and $\mathrm{Zn}$ were analyzed using an inductively coupled plasma optical emission spectrometer (SPS5510 CCD Simultaneous ICP-OES; SII Nano Technology Inc., Japan).

The $\mathrm{HCO}_{3}{ }^{-}$concentration was titrated with standard sulfuric acid of $0.01 \mathrm{M}$. The $\mathrm{pH}$ was measured using a pH meter (HM-21P; DKK-TOA Corp., Japan).

Then $\mathrm{SO}_{4}{ }^{2-}$ and $\mathrm{Ca}^{2+}$ were divided, respectively, into two components by their origins of sea salt (ss-) and non-sea salt (nss-). The non-sea salt components were calculated based on the composition ratio of Ocean Observation Guideline ${ }^{32)}$ with the following two assumptions: (i) all $\mathrm{Na}^{+}$in the rainwater was from the sea salt; (ii) the ratios of the component's concentrations were not changed in the ocean, the atmosphere (cloud), and the rainwater. The equations used for calculations are as follows:

$$
\begin{array}{r}
n s s-\mathrm{SO}_{4}^{2-} \text { concentration }=\left(\mathrm{SO}_{4}^{2-} \text { concentration }\right) \\
-0.251 \times\left(\mathrm{Na}^{+} \text {concentration }\right) \\
n s s-\mathrm{Ca}^{2+} \text { concentration }=\left(\mathrm{Ca}^{2+} \text { concentration }\right) \\
-0.038 \times\left(\mathrm{Na}^{+} \text {concentration }\right)(2)
\end{array}
$$

$\mathrm{Na}^{+}$is adopted instead of $\mathrm{Cl}^{-}$because the main source of $\mathrm{Cl}^{-}$is not only the sea salt but also the anthropogenic pollution (industrial waste incinerators, municipal waste incinerators, and other factors) $)^{33)}$.

Meteorological data such as the precipitation amount, wind direction, and wind velocity were ob- tained from data from Tsu Local Meteorological Observatory observed using the Automated Meteorological Data Acquisition System (AMeDAS) ${ }^{34)}$.

The trajectory over a wide area was calculated from the GPV data of Japan Meteorological Agency using trajectory analysis (METEX) ${ }^{35)}$. The isentropic trajectory was reversed to $120 \mathrm{hr}$ before the $500 \mathrm{~m}$ level. The starting point (red point) was Tsu City. Trajectory analysis was implemented as described in earlier reports ${ }^{11)}$.

\section{RESULTS AND DISCUSSION}

Section (1) explains the ion balance. Section (2) shows the results of rainwater from rain events obtained from 31 August 2001 through 14 December 2012. Results were the average of each rain event with the intention of elucidating the average and overall characteristics. For more details related to the characteristics, Section (3) discusses the results of fractionally sampled rainwater, with concentrations measured from rainwater samples collected during short periods of one to several hours sequentially. Section (4) describes variations in the concentrations calculated for hourly sampled events. In this study, the concentration measurements of many items were prioritized to ascertain the average and overall characteristics of rain events. Only one successful observation was made for the hourly variation. Collecting more varied data remains as a subject for future study.

Discussions of the effects of total precipitation, wind velocity, and wind direction on the concentration are presented in Sections (5), (6), and (7), respectively. Then, the comprehensive effect of the meteorological condition by the principal component analysis is discussed in Section (8). Section (9) presents a description of the correlation between $\mathrm{Pb}$ and acid concentrations. Section (10) explains the $\mathrm{Pb} / \mathrm{Zn}$ ratio.

\section{(1) Ion balance}

Fig.2 depicts the ion balance for all collected rain samples examined in this study $(n=68)$ from 31 August 2011 through 14 December 2012. The anions and cations are well balanced with the correlation coefficient of $0.989(p<0.01)$.

Fig.3 exhibits the ionic balances $\left(R 1^{36)}\right)$ of all rain samples. $R 1$ is calculated by the following equation:

$$
R 1=100 \times(C-A) /(C+A)
$$

$A$ : total equivalent concentration of anions $(\mu \mathrm{eq} / \mathrm{L})$ $C$ : total equivalent concentration of cations $(\mu \mathrm{eq} / \mathrm{L})$

The red broken line in Fig.3 shows the allowable range for $R 1$.

The measured data are almost within the allowable 


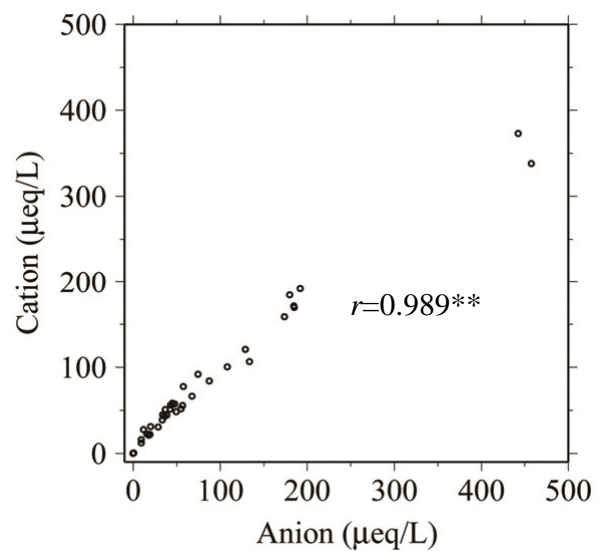

Fig.2 Correlation chart between total anion and total cation equivalent concentration in precipitations collected in Tsu City (all rain samples measured from August 2011 to December 2012). ${ }^{* *} p<0.01, n=68$ (All collected samples).

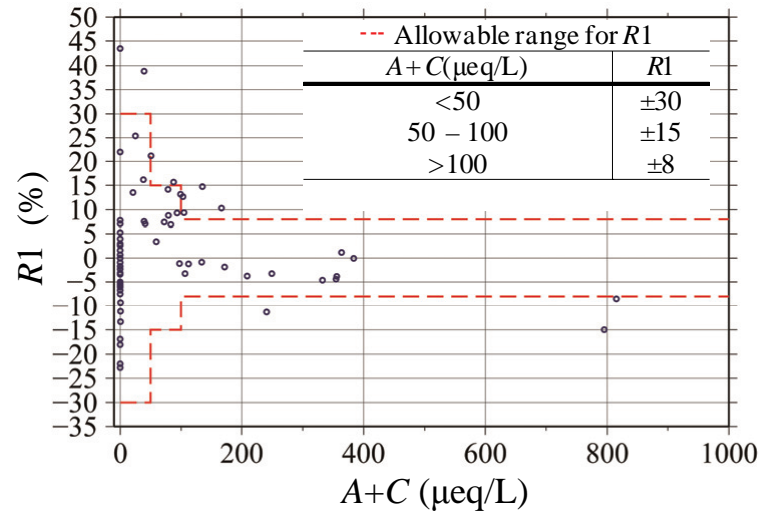

Fig.3 Correlation chart between "total anion and total cation" and " $R 1$ " (all rain samples measured from August 2011 to December 2012). Red broken line is the allowable range for $R 1 . n=68$ (Same as Fig.2).

Table 3 Sample Number and sampling date of rain events.

\begin{tabular}{|c|c|c|c|c|}
\hline \multirow[b]{2}{*}{$\begin{array}{l}\text { Sample- } \\
\text { No. }\end{array}$} & \multicolumn{2}{|c|}{ Sampling period } & \multirow[b]{2}{*}{$\begin{array}{l}\text { Duration time } \\
\text { (hh:mm) }\end{array}$} & \multirow[b]{2}{*}{ Types of rain (factor) ${ }^{34)}$} \\
\hline & $\begin{array}{c}\text { Start time } \\
\text { yyyy/mm/dd hh:mm JST }\end{array}$ & $\begin{array}{c}\text { End time } \\
\text { yyyy/mm/dd hh:mm JST }\end{array}$ & & \\
\hline M1 & 2011/08/31 23:00 & 2011/09/01 03:00 & $4: 00$ & Drizzle (The low pressure) \\
\hline M2 & 2011/09/02 10:00 & 2011/09/02 20:00 & $10: 00$ & Storm (Typhoon Talas (1112)) \\
\hline${ }^{+} \mathrm{M} 3$ & 2011/09/16 12:00 & 2011/09/17 10:00 & 22:00 & Storm (Typhoon Roke (1115)) \\
\hline${ }^{+} \mathrm{M} 4$ & 2011/09/19 17:00 & $2011 / 09 / 2015: 00$ & $22: 00$ & Storm (Typhoon Roke (1115)) \\
\hline${ }^{+}$M5 & $2011 / 10 / 0511: 00$ & 2011/10/05 23:00 & $12: 00$ & Drizzle (The cold air mass and the pressure trough) \\
\hline${ }^{+} \mathrm{M} 6$ & 2011/10/14 14:00 & 2011/10/15 24:00 & $34: 00$ & Drizzle (The front and the pressure trough) \\
\hline${ }^{+} \mathrm{M} 7$ & 2011/10/21 20:00 & $2011 / 10 / 2219: 00$ & 23:00 & Drizzle (The low pressure and the pressure trough) \\
\hline M8 & 2011/10/30 14:00 & 2011/10/31 03:00 & $13: 00$ & Light rain ( The low pressure) \\
\hline M9 & 2011/11/05 19:00 & 2011/11/06 06:00 & $11: 00$ & Light rain (The low pressure) \\
\hline${ }^{+} \mathrm{M} 10$ & 2011/11/11 07:00 & 2011/11/11 14:00 & $7: 00$ & Light rain (The front and the pressure trough) \\
\hline${ }^{+} \mathrm{M} 11$ & 2011/11/19 03:00 & 2011/11/19 17:00 & $14: 00$ & Rain (The front and the pressure trough) \\
\hline M12 & 2011/12/02 03:00 & 2011/12/02 08:00 & $5: 00$ & Light rain (The low pressure and the pressure trough) \\
\hline M13 & 2011/12/03 03:00 & 2011/12/03 09:00 & $6: 00$ & Light rain (The low pressure and the pressure trough) \\
\hline${ }^{+} \mathrm{M} 14$ & 2012/01/19 14:00 & 2012/01/21 22:00 & $56: 00$ & Rain (The pressure trough) \\
\hline${ }^{+} \mathrm{M} 15$ & 2012/04/11 08:30 & 2012/04/11 16:30 & 8:00 & Light rain (The low pressure) \\
\hline M16 & $2012 / 04 / 1317: 45$ & $2012 / 04 / 1322: 30$ & $4: 45$ & Light rain (The low pressure) \\
\hline M17 & $2012 / 04 / 2009: 30$ & $2012 / 04 / 2013: 00$ & $3: 30$ & Light rain (The low pressure) \\
\hline M18 & 2012/04/21 23:00 & 2012/04/22 03:00 & $4: 00$ & Light rain (The low pressure) \\
\hline${ }^{+} \mathrm{M} 19$ & $2012 / 04 / 2210: 00$ & $2012 / 04 / 2311: 30$ & $25: 30$ & Rain (The low pressure) \\
\hline M20 & 2012/04/26 09:00 & 2012/04/26 14:30 & $5: 30$ & Light rain (The low pressure) \\
\hline M21 & 2012/05/15 08:30 & 2012/05/15 16:30 & $8: 00$ & Drizzle (The low pressure) \\
\hline M22 & $2012 / 05 / 2816: 30$ & $2012 / 05 / 2817: 00$ & $0: 30$ & Thunderstorm (The cold air mass) \\
\hline M23 & 2012/05/29 13:00 & 2012/05/29 18:00 & $5: 00$ & Thunderstorm (The cold air mass) \\
\hline${ }^{+} \mathrm{M} 24$ & 2012/06/08 18:00 & 2012/06/09 04:00 & $10: 00$ & Drizzle (The seasonal (spring) rain front) \\
\hline M25 & 2012/06/19 08:00 & 2012/06/19 14:00 & $6: 00$ & Storm (Typhoon Guchol (1204)) \\
\hline${ }^{+} \mathrm{M} 26$ & 2012/06/21 12:00 & 2012/06/21 16:00 & 4:00 & Light rain (The seasonal (spring) rain front) \\
\hline${ }^{+} \mathrm{M} 27$ & 2012/09/18 10:00 & 2012/09/18 17:00 & 7:00 & Storm (Typhoon Bolaven (1215)) \\
\hline M28 & 2012/10/18 12:00 & 2012/10/18 18:00 & $6: 00$ & Light rain (The front) \\
\hline M29 & 2012/10/23 10:00 & 2012/10/23 12:00 & 2:00 & Light rain (The front) \\
\hline${ }^{+} \mathrm{M} 30$ & 2012/11/17 13:00 & 2012/11/17 19:00 & $6: 00$ & Rain (The low pressure and the pressure trough) \\
\hline M31 & 2012/12/14 22:00 & 2012/12/15 12:00 & $14: 00$ & Light rain (The low pressure and the pressure trough) \\
\hline
\end{tabular}

+fractionally sampled rainwater

ranges. The outliers are also included in the following discussions.

\section{(2) Summary of rainwater of rain events (Sample Nos. M1-M31)}

Table 3 presents the sample number and sampling date of rain events. Table 4 presents the measured elements and their concentrations with wind information from 31 August 2011 through 14 December 2012 (data of rain event, Sample Nos. M1-M31). The measured concentrations were the average for each event. The wind velocity and direction were time averages.

The data of concentration and $\mathrm{pH}$ were the 
weighted averages by the precipitation amount. Sample Nos. marked + of Nos. 3, 4, 5, 6, 7, 10, 11, $14,15,19,24,26,27$, and 30 were collected fractionally.

The $\mathrm{pH}$ in Tsu City was 5.0. The national average from April 2011 through March 2012 was 4.8, according to the Ministry of the Environment data ${ }^{37)}$. They showed no significant difference $(p<0.01)$. Moreover, nss- $\mathrm{SO}_{4}{ }^{2-}$ and $\mathrm{ss}-\mathrm{SO}_{4}{ }^{2-}, \mathrm{NO}_{3}{ }^{-}, \mathrm{Cl}^{-}, \mathrm{NH}_{4}{ }^{+}$, $\mathrm{Na}^{+}, \mathrm{K}^{+}, \mathrm{Mg}^{2+}$, nss- $\mathrm{Ca}^{2+}$ and ss-Ca ${ }^{2+}$ concentrations in Tsu City did not differ from the national average $(p<0.01)$.

The concentrations of $\mathrm{NO}_{3}{ }^{-}$and $\mathrm{NO}_{2}^{-}$were the highest at M9 on 5 November 2011. Concentrations of nss- $\mathrm{SO}_{4}{ }^{2-}, \mathrm{F}^{-}, \mathrm{NH}_{4}{ }^{+}$, nss-Ca ${ }^{2+}, \mathrm{Ba}, \mathrm{Cu}, \mathrm{Pb}$ and $\mathrm{Zn}$ were the highest at M23 on 29 May 2012. Concentrations of $\mathrm{Cl}^{-}$, ss- $\mathrm{SO}_{4}{ }^{2-}, \mathrm{Na}^{+}, \mathrm{Mg}^{2+}$, and $\mathrm{ss}-\mathrm{Ca}^{2+}$ were the highest at M25 during Typhoon Guchol (1204).

\section{a) Correlation of concentrations of ions and trace metals}

A correlation matrix of concentrations of ions and trace metals is shown as Table $5(n=31)$. From the obtained correlation coefficients, the ions and trace metals are classified into three groups from the viewpoint of their main sources. The groups are: (i) the ions of which the main source is sea salt (ㅌea $\underline{\text { Salt }}$ Ion Group, SSI group), (ii) the ions of which the main source is the anthropogenic pollution and soil (Anthropogenic Pollution and Soil Ion Group, ASI group), and (iii) trace metals of which the main source is anthropogenic pollution and soil (Anthropogenic Pollution and Soil Trace Metal Group, ASM group). This classification is explained as follows:

Of 31 mole ratios of $\mathrm{Cl}^{-} / \mathrm{Na}^{+}, 18$ data were higher than the seawater value of $1.18^{38)}$. Although the slight existence of nss- $\mathrm{Cl}^{-}$was indicated, the mutual correlations of $\mathrm{Cl}^{-}, \mathrm{Na}^{+}, \mathrm{K}^{+}, \mathrm{Mg}^{2+}$, $\mathrm{ss}-\mathrm{SO}_{4}{ }^{2-}$, and $\mathrm{ss}-\mathrm{Ca}^{2+}$ were highly positive $(r=0.683-1.000, p<0.01)$. Their main source was regarded as the sea salt. Therefore, they were classified as the SSI group.

Mutual correlations of $\mathrm{F}^{-}, \mathrm{NO}_{3}^{-}, \mathrm{NH}_{4}^{+}$and nss- $\mathrm{SO}_{4}{ }^{2-}$ were highly positive $(r=0.761-0.950$, $p<0.01)$. Mutual correlations of the $\mathrm{Al}, \mathrm{Fe}, \mathrm{Mn}, \mathrm{Pb}$, and $\mathrm{Zn}$ trace metals were highly positive $(r=0.607-$ 0.957, $p<0.01$ ).

$\mathrm{NH}_{4}{ }^{+}$is reportedly related with anthropogenic pollution ${ }^{39), 40)}$. The ions and trace metals that showed highly positive correlation with $\mathrm{NH}_{4}{ }^{+}$were $\mathrm{F}^{-}, \mathrm{NO}_{3}{ }^{-}$, nss-SO ${ }_{4}{ }^{2-}, \mathrm{Al}, \mathrm{Fe}, \mathrm{Mn}, \mathrm{Pb}$, and $\mathrm{Zn}(r=0.525-0.950$, $p<0.01)$. Their main source was regarded as anthropogenic pollution.

The $\mathrm{F}^{-}$concentration is high in China ${ }^{41), 42)}$ and $\mathrm{F}^{-}$is reported to be related with yellow sand (kosa). The ions and trace metals that had highly positive corre-

Table 4 Summary of observed items of rain events.

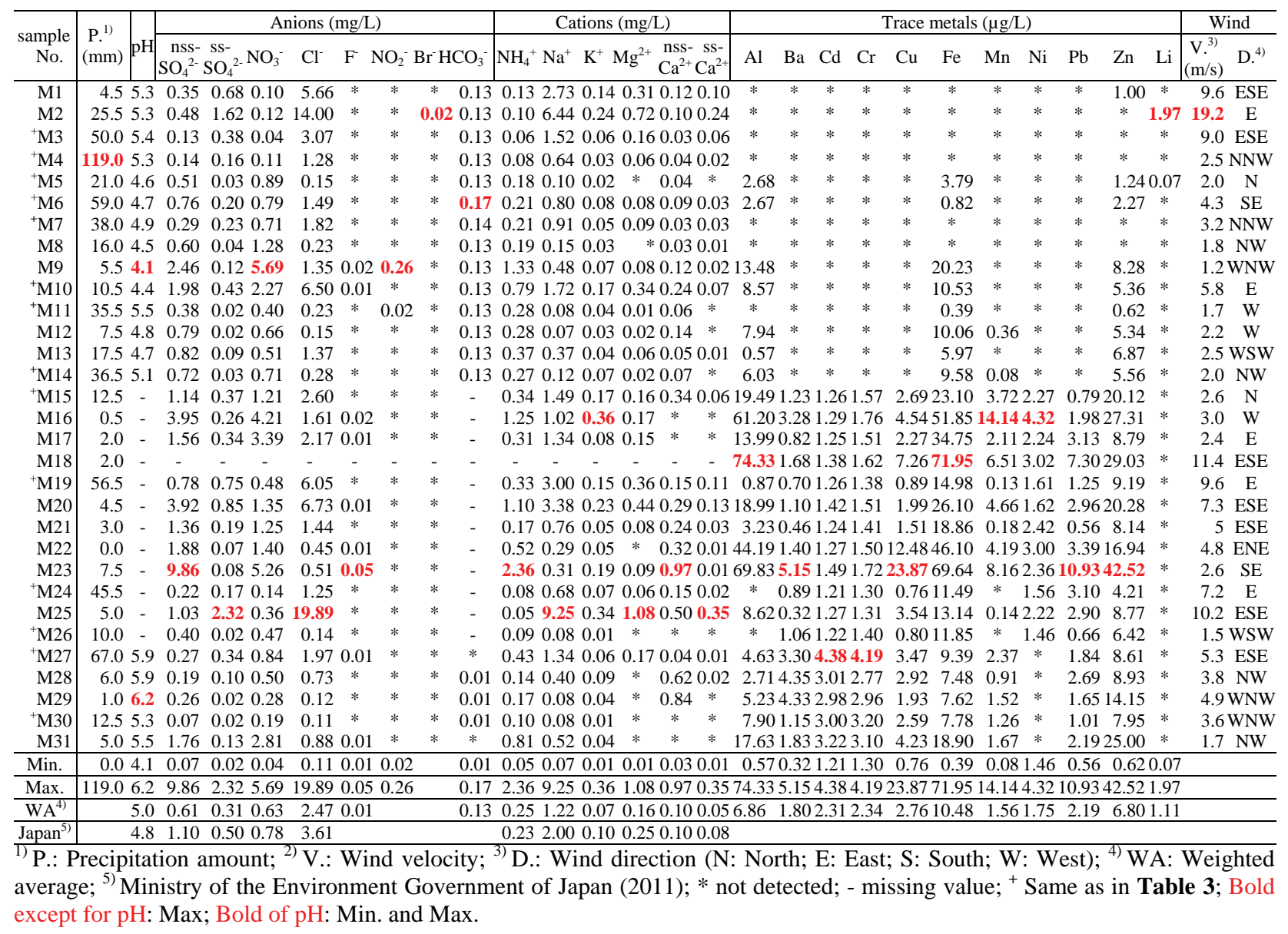


lation with $\mathrm{F}^{-}$were $\mathrm{NO}_{3}{ }^{-}, \mathrm{NH}_{4}{ }^{+}$, nss- $\mathrm{SO}_{4}{ }^{2-}, \mathrm{Al}, \mathrm{Fe}$, $\mathrm{Mn}, \mathrm{Pb}$ and $\mathrm{Zn}(r=0.611-0.950, p<0.01)$. Much nss- $-\mathrm{Ca}^{2+}$ was contained in the rainwater when yellow sand was observed. It showed highly positive correlation with nss-SO ${ }_{4}^{2-}$ and $\mathrm{Pb}(r=0.515,0.535$, respectively, $p<0.01$ ).

Yellow sand reportedly contains soil and anthropogenic pollutants ${ }^{43}$, ${ }^{44)}$. From the discussion presented above, the main sources of $\mathrm{F}^{-}, \mathrm{NO}_{3}^{-}, \mathrm{NH}_{4}^{+}$, nss- $\mathrm{SO}_{4}{ }^{2-}, \mathrm{nss}_{-} \mathrm{Ca}^{2+}, \mathrm{Al}, \mathrm{Fe}, \mathrm{Mn}, \mathrm{Pb}$, and $\mathrm{Zn}$ were regarded as anthropogenic pollution and soil. Considering the chemical forms, the ions of $\mathrm{F}^{-}, \mathrm{NO}_{3}{ }^{-}$, $\mathrm{NH}_{4}{ }^{+}$, nss- $\mathrm{SO}_{4}{ }^{2-}, \mathrm{nss}_{-} \mathrm{Ca}^{2+}$ were classified as ASI group; the $\mathrm{Al}, \mathrm{Fe}, \mathrm{Mn}, \mathrm{Pb}$, and $\mathrm{Zn}$ trace metals were classified as ASM group.

\section{b) Correlation of observed elements and meteor- ological conditions}

For Sample Nos. M1-M31 ( $n=31)$, a correlation matrix of the concentrations and meteorological conditions is shown in Table 6. Conditions that af- fect the concentrations were regarded as the precipitation amount, the wind velocity, and the wind direction.

In general, the concentration tends to be higher with more antecedent dry weather days ${ }^{45)}$. However, correlation of the concentrations in the rainwater of rain events and the antecedent dry weather days was not apparent in our results $(p<0.05)$.

The collection time does not strongly affect the concentration. The concentration of Fe showed weak and negative correlation $(r=-0.372, p<0.05)$. No element had a coefficient larger than 0.5 .

Meteorological conditions that were highly correlated with the concentrations were the precipitation amount and wind velocity. They are discussed in Sections (5) and (6). Regarding wind direction, only ESE and SE were observed to have a significant and positive correlation with the concentrations. This is explained in Section (7).

Table 5 Correlation matrix of concentrations of elements in rain water (Sample Nos. M1 $\triangleq$ M31, $n=31$ ).

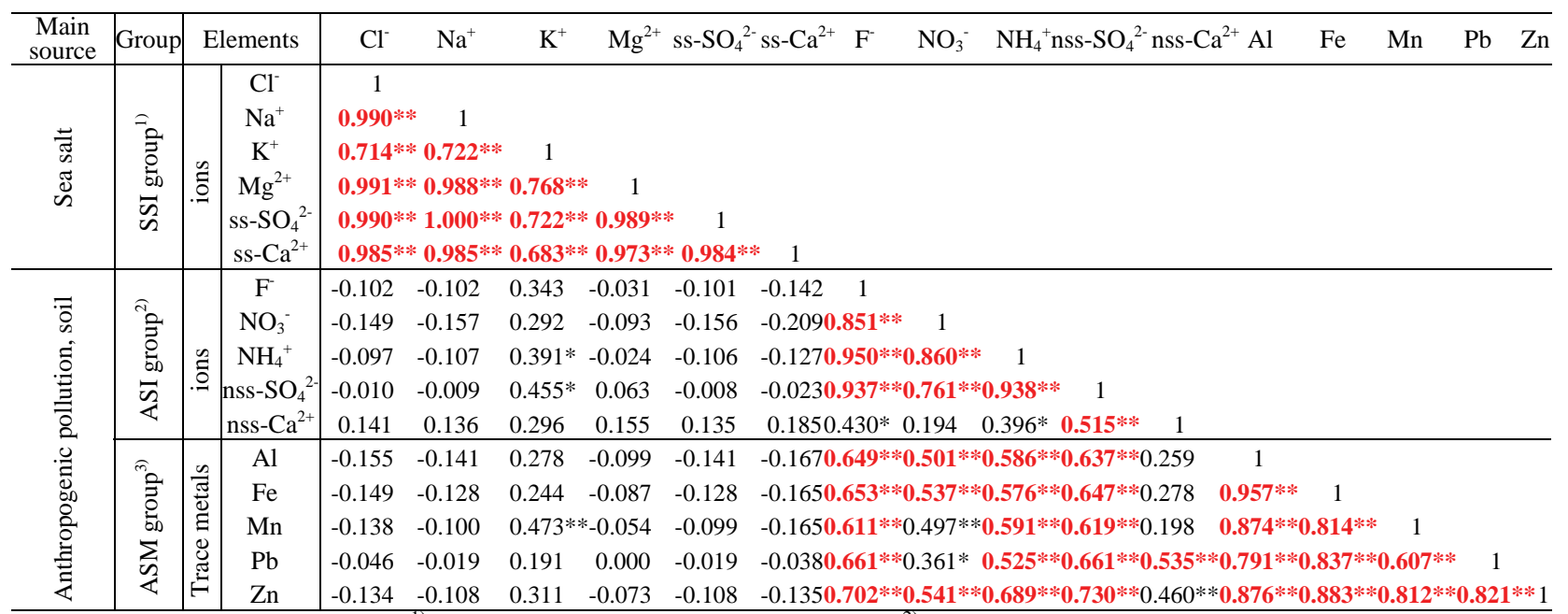

Bold: $r>0.5 ;{ }^{*} p<0.05 ;{ }^{* *} p<0.01 ;{ }^{1)}$ SSI group: This main source is sea salt; ${ }^{2}$ ASI group: These main sources are anthropogenic pollution and soil; ${ }^{3)} \mathrm{ASM}$ group: These main sources are anthropogenic pollution and soil.

Table 6 Correlation matrix of concentrations and meteorological conditions (Sample Nos. M1 $\cong$ M31, $n=31$ ).

\begin{tabular}{|c|c|c|c|c|c|c|c|c|c|c|c|}
\hline \multirow{2}{*}{ Group } & \multirow{2}{*}{ Elements } & \multirow{2}{*}{$\begin{array}{c}\text { A.D.W.D. } \\
\text { (day) }\end{array}$} & \multirow{2}{*}{$\begin{array}{c}\mathrm{H}^{2 \text { ) }} \\
\text { (hour) }\end{array}$} & \multirow{2}{*}{$\begin{array}{c}\mathrm{P}^{3)} \\
(\mathrm{mm})\end{array}$} & \multirow{2}{*}{$\begin{array}{l}\text { W.V. }{ }^{4)} \\
(\mathrm{m} / \mathrm{s})\end{array}$} & \multicolumn{6}{|c|}{ Wind direction } \\
\hline & & & & & & ENE & E & ESE & SE & WSW & W WNW NW NNW \\
\hline \multirow{6}{*}{$\begin{array}{l}\text { SSI } \\
\text { group }\end{array}$} & $\mathrm{Cl}^{-}$ & -0.305 & -0.035 & -0.051 & $0.694^{* * *}$ & $-0.083-0.097$ & 0.337 & $0.357^{*}$ & -0.106 & -0.121 & $-0.158-0.168-0.198-0.072$ \\
\hline & $\mathrm{Na}^{+}$ & -0.313 & -0.023 & -0.034 & $0.696^{* *}$ & $-0.067-0.094$ & 0.300 & $0.390^{*}$ & -0.099 & -0.143 & $-0.151-0.181-0.196-0.070$ \\
\hline & $\mathrm{K}^{+}$ & -0.219 & -0.112 & -0.206 & $0.403^{*}$ & $-0.006-0.094$ & 0.215 & 0.169 & 0.109 & -0.207 & $0.165-0.204-0.167-0.164$ \\
\hline & $\mathrm{Mg}^{2+}$ & -0.318 & -0.047 & -0.052 & $0.675^{* *}$ & $-0.081-0.119$ & 0.328 & $0.390^{*}$ & -0.075 & -0.137 & $-0.120-0.176-0.243-0.087$ \\
\hline & $\mathrm{ss}-\mathrm{SO}_{4}{ }^{2-}$ & -0.313 & -0.024 & -0.034 & $0.696^{* * *}$ & $-0.067-0.095$ & 0.300 & $0.390^{*}$ & -0.099 & -0.144 & $-0.150-0.181-0.196-0.070$ \\
\hline & ss-Ca ${ }^{2+}$ & -0.299 & 0.003 & -0.040 & $\underline{0.707^{* * *}}$ & $-0.046-0.080$ & 0.259 & $0.384^{*}$ & -0.080 & -0.132 & $-0.187-0.158-0.181-0.063$ \\
\hline \multirow{5}{*}{$\begin{array}{l}\text { ASI } \\
\text { group }\end{array}$} & $\mathrm{F}^{-}$ & 0.251 & -0.224 & -0.236 & -0.212 & -0.1260 .093 & -0.036 & -0.106 & $0.523^{* *}$ & -0.126 & $0.0590 .059-0.089-0.126$ \\
\hline & $\mathrm{NO}_{3}^{-}$ & 0.349 & -0.140 & -0.350 & $-0.386^{*}$ & -0.0340 .020 & 0.012 & -0.246 & 0.316 & -0.133 & $0.114 \quad 0.180 \quad 0.022-0.147$ \\
\hline & $\mathrm{NH}_{4}^{+}$ & 0.272 & -0.151 & -0.269 & -0.263 & -0.0800 .040 & -0.078 & -0.146 & $0.464^{* *}$ & -0.096 & $0.1270 .081-0.045-0.141$ \\
\hline & nss- $\mathrm{SO}_{4}{ }^{2-}$ & 0.276 & -0.186 & -0.299 & -0.169 & -0.0620 .061 & -0.060 & -0.073 & $\underline{0.573^{* *}}$ & -0.092 & $0.079-0.058-0.092-0.148$ \\
\hline & nss-Ca ${ }^{2+}$ & 0.111 & -0.294 & -0.301 & 0.032 & 0.0090 .105 & -0.097 & -0.016 & $0.379^{*}$ & -0.170 & $-0.1550 .188-0.002-0.159$ \\
\hline \multirow{5}{*}{$\begin{array}{l}\text { ASM } \\
\text { group }\end{array}$} & $\mathrm{Al}$ & 0.064 & -0.343 & $-0.387^{*}$ & 0.013 & $\begin{array}{lll}-0.021 & 0.282\end{array}$ & -0.173 & 0.078 & 0.303 & -0.160 & $0.166-0.062-0.116-0.164$ \\
\hline & $\mathrm{Fe}$ & 0.038 & $-0.372^{*}$ & $-0.429^{*}$ & 0.000 & -0.0400 .283 & -0.045 & 0.101 & 0.259 & -0.102 & $0.076-0.076-0.147-0.224$ \\
\hline & Mn & -0.045 & -0.337 & -0.320 & -0.045 & 0.0150 .149 & -0.176 & 0.053 & 0.205 & -0.144 & $0.336-0.080-0.127-0.144$ \\
\hline & $\mathrm{Pb}$ & & -0.347 & -0.285 & 0.100 & -0.1300 .142 & -0.012 & 0.152 & $0.436^{*}$ & -0.137 & $-0.125-0.094-0.055-0.174$ \\
\hline & $\mathrm{Zn}$ & 0.110 & -0.344 & $-0.439^{*}$ & -0.079 & 0.0240 .130 & -0.185 & 0.057 & 0.328 & -0.081 & $0.0430 .0120 .004-0.254$ \\
\hline
\end{tabular}

${ }^{1)}$ A.D.W.D.: Antecedent dry weather days; ${ }^{2} \mathrm{H}$.: Collecting time (Period of rain event); ${ }^{3)}$ P.: Precipitation amount; ${ }^{4)}$ W.V.: Wind velocity; Bold and underlined: $r>\mathbf{0 . 5 0 0}$; Bold: $r>\mathbf{0 . 3 5 5 * ;}{ }^{*} p<0.05 ; * * p<0.01$ 
Table 7 Correlation matrix of concentrations of elements $(n=51)$.

\begin{tabular}{|c|c|c|c|c|c|c|c|c|c|c|c|c|c|c|c|c|}
\hline Group & Elements & $\mathrm{Cl}^{-}$ & $\mathrm{Na}^{+}$ & $\mathrm{K}^{+}$ & $\mathrm{Mg}^{2+}$ & $\begin{array}{c}\mathrm{SS} \\
-\mathrm{SO}_{4}{ }^{2-} \\
\end{array}$ & $\begin{array}{l}\text { Ss } \\
-\mathrm{Ca}^{2+}\end{array}$ & $\mathrm{F}^{-}$ & $\mathrm{NO}_{3}{ }^{-}$ & $\mathrm{NH}_{4}^{+}$ & $\begin{array}{c}\mathrm{nss}{ }^{-\mathrm{SO}_{4}{ }^{2-}} \\
\end{array}$ & $\begin{array}{c}\text { nss } \\
-\mathrm{Ca}^{2+}\end{array}$ & $\mathrm{Al}$ & $\mathrm{Fe}$ & $\mathrm{Mn}$ & $\mathrm{Pb}$ \\
\hline \multirow{6}{*}{$\begin{array}{l}\text { SSI } \\
\text { group }\end{array}$} & $\mathrm{Cl}^{-}$ & $1_{* * *}$ & & & & & & & & & & & & & & \\
\hline & $\mathrm{Na}^{+}$ & $0.977^{* * *}$ & $1_{\text {*** }}$ & & & & & & & & & & & & & \\
\hline & $\mathrm{K}^{+}$ & $0.867^{* *}$ & $0.863^{* *}$ & 1 & & & & & & & & & & & & \\
\hline & $\mathrm{Mg}^{2+}$ & $0.976^{* *}$ & $0.973^{* *}$ & $0.842^{* *}$ & 1 & & & & & & & & & & & \\
\hline & ss- $-\mathrm{SO}_{4}^{2-}$ & $0.977^{* * *}$ & $1.000^{* *}$ & $0.863^{* *}$ & $0.973^{* * *}$ & 1 & & & & & & & & & & \\
\hline & ss-Ca ${ }^{2+}$ & $0.971^{* * *}$ & $0.990^{* *}$ & $0.851^{* *}$ & $0.968^{* *}$ & $0.990^{* * *}$ & 1 & & & & & & & & & \\
\hline \multirow{5}{*}{$\begin{array}{l}\text { ASI } \\
\text { group }\end{array}$} & $\mathrm{F}^{-}$ & 0.206 & 0.132 & 0.230 & 0.300 & 0.132 & 0.143 & 1 & & & & & & & & \\
\hline & $\mathrm{NO}_{3}^{-}$ & 0.214 & 0.118 & 0.274 & 0.278 & 0.118 & 0.141 & $0.809^{* * *}$ & 1 & & & & & & & \\
\hline & $\mathrm{NH}_{4}^{+}$ & $0.382^{* *}$ & $0.312^{*}$ & 0.353 & $0.490^{* *}$ & $0.312^{*}$ & $0.337^{*}$ & $0.819^{* * *}$ & $0.836^{* * *}$ & 1 & & & & & & \\
\hline & nss-SO ${ }_{4}^{2-}$ & $0.594^{* * *}$ & $0.501^{* *}$ & $0.671^{* *}$ & $0.568^{* * *}$ & $0.501^{* * *}$ & $0.516^{* * *}$ & $0.508^{* *}$ & $0.715^{* *}$ & $0.634^{* *}$ & 1 & & & & & \\
\hline & nss- $-\mathrm{Ca}^{2+}$ & $0.365^{* *}$ & $0.378^{* *}$ & $0.487^{* *}$ & $0.408^{* *}$ & $0.378^{* *}$ & $0.399^{* *}$ & 0.233 & 0.265 & $0.309^{*}$ & $0.448^{* *}$ & 1 & & & & \\
\hline \multirow{5}{*}{$\begin{array}{l}\text { ASM } \\
\text { group }\end{array}$} & $\mathrm{Al}$ & 0.154 & 0.134 & 0.386 & 0.162 & 0.134 & 0.133 & $0.460^{* *}$ & $0.573^{* * *}$ & $0.314^{*}$ & $0.581^{s * m}$ & $0.309^{*}$ & 1 & & & \\
\hline & $\mathrm{Fe}$ & $0.496^{* * *}$ & $0.492^{* * *}$ & $0.664^{* * *}$ & $0.503^{* * *}$ & $0.492^{* * *}$ & $0.475^{* * *}$ & $0.277^{*}$ & $0.382^{* * *}$ & $0.341^{*}$ & $0.647^{* *}$ & $0.461^{* *}$ & $0.670^{* * *}$ & 1 & & \\
\hline & Mn & 0.006 & 0.047 & 0.135 & 0.134 & 0.047 & 0.051 & $0.529^{* * *}$ & $0.411^{* *}$ & $0.449^{* *}$ & 0.105 & 0.197 & $0.541^{* *}$ & $0.325^{*}$ & 1 & \\
\hline & $\mathrm{Pb}$ & 0.098 & 0.140 & 0.176 & 0.108 & 0.140 & 0.131 & 0.005 & 0.091 & 0.054 & 0.019 & $0.303^{*}$ & 0.113 & $0.397^{* *}$ & 0.127 & \multirow{2}{*}{$\begin{array}{c}1 \\
0.317^{*}\end{array}$} \\
\hline & $\mathrm{Zn}$ & $0.278^{*}$ & 0.311 & $0.512^{* *}$ & $0.304^{*}$ & $0.311^{*}$ & $0.290^{*}$ & $0.288^{*}$ & $0.334^{*}$ & 0.199 & $0.512^{* *}$ & $0.516^{* *}$ & $0.823^{* *}$ & $0.832^{* *}$ & $0.535^{* *}$ & \\
\hline
\end{tabular}

Bold: $r>0.5 ;{ }^{*} p<0.05 ;{ }^{*} p<0.01$

Table 8 Correlation matrix of concentrations and meteorological conditions ( $n=51)$.

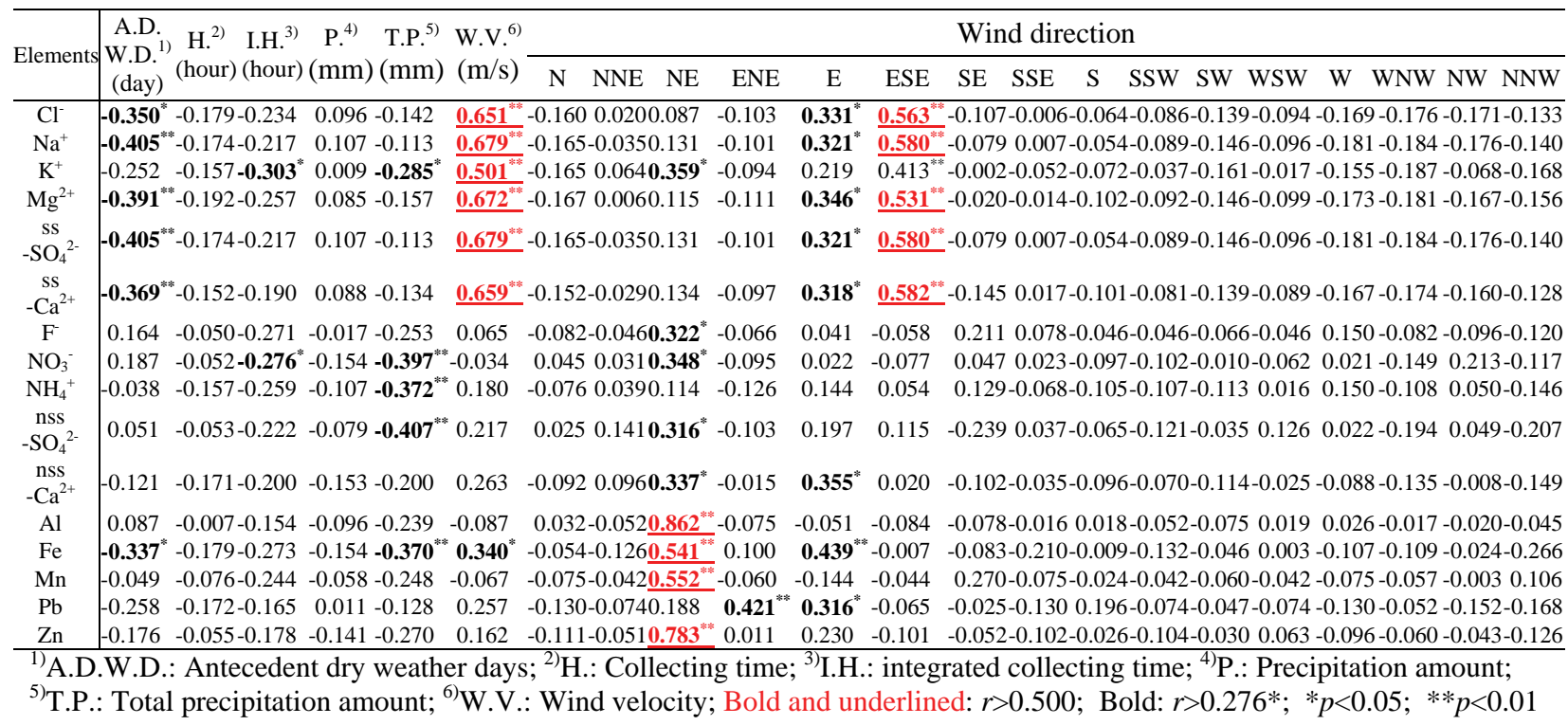

\section{3) Summary of fractionally sampled rainwater (Sample Nos. M3, M4, M5, M6, M7, M10, M11, M14, M15, M19, M24, M26, M27, M30)}

Samples marked + in Table 3 in which the rainwater was fractionally sampled and collected sequentially are discussed in this section.

Our earlier study ${ }^{46)}$ conducted in August 2010 January 2011 collected rain samples of a certain volume $(50 \mathrm{ml})$ not every hour but sequentially during rain events, and three times during one event, i.e., in the initial period, in the middle and at the end. Then the average value of each period was obtained. Concentrations of both positive and negative ion components generally showed the highest in the initial period, then at the end, and last at the middle. We also collected water samples each hour during rain events from August 2010 through December 2012.

\section{a) Correlation of concentrations of ions and trace metals}

A correlation matrix of the measured concentra- tions of ions and trace metals is presented in Table 7 $(n=51)$. The observed elements were classified into three groups in this section of the fractionally sampled rainwater in the same way as Section (2) a): SSI group, ASI group, and ASM group for the following reasons:

The mutual correlations of $\mathrm{Cl}^{-}, \mathrm{Na}^{+}, \mathrm{K}^{+}, \mathrm{Mg}^{2+}$, ss- $-\mathrm{SO}_{4}{ }^{2-}$ and $\mathrm{ss}-\mathrm{Ca}^{2+}$ were strongly positive $(r=$ $0.842-1.000, p<0.01)$. The correlations of $\mathrm{Na}^{+}$and $\mathrm{Cl}^{-}, \mathrm{K}^{+}, \mathrm{Mg}^{2+}$, $\mathrm{ss}^{-\mathrm{SO}_{4}}{ }^{2-}$ and ss-Ca ${ }^{2+}$ were also strongly positive $(r=0.863-1.000, p<0.01)$. Then the source of $\mathrm{Cl}^{-}, \mathrm{Na}^{+}, \mathrm{K}^{+}, \mathrm{Mg}^{2+}$, ss- $\mathrm{SO}_{4}{ }^{2-}$ and $\mathrm{ss}-\mathrm{Ca}^{2+}$ was inferred to be sea salt.

The mutual correlations of $\mathrm{F}^{-}, \mathrm{NO}_{3}{ }^{-}, \mathrm{NH}_{4}{ }^{+}$and nss- $\mathrm{SO}_{4}{ }^{2-}$ were strongly positive $(r=0.508-0.836$, $p<0.01)$. Their source was regarded as anthropogenic pollution.

$\mathrm{Zn}$ had strongly positive correlation with nss- $\mathrm{SO}_{4}{ }^{2-}, \mathrm{nss}^{-\mathrm{Ca}^{2+}}, \mathrm{Al}, \mathrm{Fe}$, and $\mathrm{Mn}(r=0.512-$ $0.832, p<0.01$ ), and also was found to have weakly 

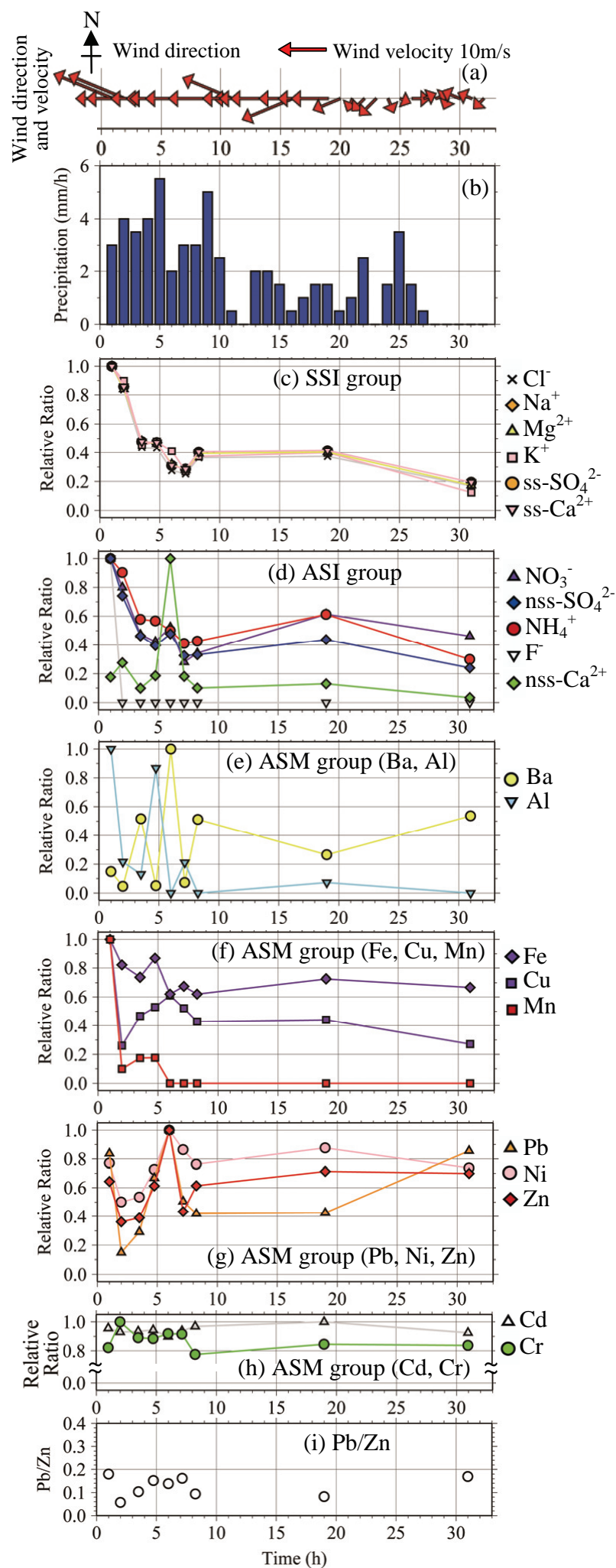

Fig.4 Time variations in (a) wind direction and wind velocity, (b) precipitation amount, ((c), (d), (e), (f), (g) and (h)) relative ratio* and (i) $\mathrm{Pb} / \mathrm{Zn}$ ratio in rain water collected in Tsu City in April 22 at 10:00 to April 23 at 11:30 in 2012 (Sample No.M19).

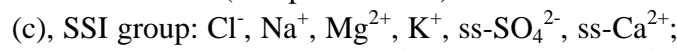

(d), ASI group: $\mathrm{NO}_{3}{ }^{-}$, nss- $\mathrm{SO}_{4}{ }^{2-}, \mathrm{NH}_{4}{ }^{+}, \mathrm{F}^{-}$, nss- $\mathrm{Ca}^{2+}$;

(e), ASM group: $\mathrm{Ba}, \mathrm{Al}$; (f), ASM group: $\mathrm{Fe}, \mathrm{Cu}, \mathrm{Mn}$;

(g), ASM group: $\mathrm{Pb}, \mathrm{Ni}, \mathrm{Zn}$; (h), ASM group: $\mathrm{Cd}, \mathrm{Cr}$.

$*$ Relative ratio $=$ concentration $/$ the maximum value. positive correlation with $\mathrm{Pb}(r=0.317, p<0.05)$. Because the source of $\mathrm{Zn}$ was inferred as anthropogenic pollution and soil ${ }^{15)}$, the source of nss- $\mathrm{SO}_{4}{ }^{2-}$, nss- $\mathrm{Ca}^{2+}, \mathrm{Al}, \mathrm{Fe}, \mathrm{Mn}$, and $\mathrm{Zn}$ was inferred to be the anthropogenic pollution and soil.

b) Correlation of observed elements and meteorological conditions

A correlation matrix of the concentrations of the observed elements and the meteorological conditions is shown in Table $8(n=51)$.

The collecting time (period of rain event) showed no correlation with concentrations, and it was deemed not to have affected the concentrations very much. The integrated collecting time had weak negative correlation with $\mathrm{K}^{+}$and $\mathrm{NO}_{3}^{-}(r=-0.303$, -0.276 , respectively, $p<0.05$ ), but it was considered not to have affected the decrease in other elements' concentrations very much.

Precipitation amount was considered not to have affected the decrease in concentrations very much. The total precipitation amount and the wind velocity, which were highly correlated with the concentrations, are discussed in Sections (5) and (6).

Reportedly, concentration is generally proportional to antecedent dry weather days ${ }^{45)}$. However, weakly negative correlation with antecedent dry weather days was shown for $\mathrm{Na}^{+}, \mathrm{Mg}^{2+}$, $\mathrm{Ss}_{-} \mathrm{SO}_{4}{ }^{2-}$, ss- $\mathrm{Ca}^{2+}$, and $\mathrm{Cl}^{-}$in the SSI group, and for $\mathrm{Fe}$ in the ASI group $(r=-0.405--0.350, p<0.05)$. No effect of antecedent dry weather days was observed clearly in our study.

(4) Hourly variation in concentrations of ion components and trace metals at one rain event (Sample No. M19)

Hourly variations in concentrations during 22-23 April 2012 are presented in Fig.4 with wind conditions.

Several studies ${ }^{47), 48)}$ have demonstrated that the concentration was high in the initial period of rain events. Another earlier study ${ }^{49)}$ showed that each concentration of $\mathrm{Cl}^{-}, \mathrm{NH}_{4}{ }^{+}$and $\mathrm{SO}_{4}{ }^{2-}$ was high in the initial period, thereby reflecting the effects of "wash-out" by the precipitation. Durana et al. ${ }^{50)}$ demonstrated that, for rain events under stable meteorological condition and in areas without local pollution, the concentration of rain components was high during the initial period. It then decreased rapidly. Kurahashi et $a l^{51)}$ examined $\mathrm{NO}_{3}^{-}$and $\mathrm{SO}_{4}{ }^{2-}$ concentrations in two rain events under a stationary front. Their samples, not collected each hour, showed that the concentrations were high in the initial period, at the end of one event, in the middle, and at the end of the other event.

In this study, the "wash-out" effect was observed for all ions of the SSI group; for $\mathrm{NO}_{3}{ }^{-}$, nss- $\mathrm{SO}_{4}{ }^{2-}$, 
$\mathrm{NH}_{4}^{+}$, and $\mathrm{F}^{-}$of the ASI group; and for $\mathrm{Fe}, \mathrm{Cu}, \mathrm{Al}$, and $\mathrm{Mn}$ of the ASM group.

\section{a) SSI group}

Fig.4(c) shows that the SSI group concentrations decreased rapidly from the maximum values in the initial period. This rapid decrease appears to show that the condensed sea salts in the atmosphere are removed by precipitation. Then the atmosphere would be cleaned to some degree and the sea salt concentrations would decrease to background levels.

The background levels are regarded as local pollution in Tsu City. The levels are low concentrations of the residual pollutants, which are always measured as a result of being emitted and diffused from sources of natural or the anthropogenic pollution ${ }^{52}$.

This phenomenon is the effect of "wash-out" by the precipitation ${ }^{39}$. The atmospheric conditions in this rain event were regarded as stable because there were no remarkable changes in the wind direction and velocity. The observed fluctuation of concentrations was found also in an earlier study ${ }^{50)}$ under fairly stable meteorological conditions.

\section{b) ASI group}

$\mathrm{NO}_{3}^{-}$, nss- $\mathrm{SO}_{4}{ }^{2-}, \mathrm{NH}_{4}{ }^{+}$, and $\mathrm{F}^{-}$of the ASI group in Fig.4(d) showed similar behavior to those of the SSI group in Fig.4(c), also reflecting the "wash-out" effect. $\mathrm{F}^{-}$, in particular, was not present after the initial period. The nss-Ca ${ }^{2+}$ showed that the concentration decreased once from the beginning and then turned up to the highest value at $6 \mathrm{hr}$. The temporary increase of the concentration by the effect of the wind direction and wind velocity was reported from an earlier study ${ }^{51)}$. However, in our study, this concentration fluctuation occurred under the condition that the wind direction and velocity did not change very much, probably because the materials were supplied continuously to the atmosphere by the transport.

\section{c) ASM group}

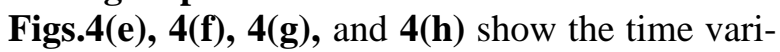
ation in the ASM group concentrations. The concentrations of $\mathrm{Ba}$ and $\mathrm{Al}$ in Fig.4(e) show large fluctuations similar to nss- $\mathrm{Ca}^{2+}$ in Fig.4(d). The main source of nss- $\mathrm{Ca}^{2+}$ is soil and $\mathrm{Ba}$ and $\mathrm{Al}$ originate mainly from soil according to Mizohata \& Mamuro ${ }^{15)}$. Thus, it is thought that the main source of $\mathrm{Ba}$ and $\mathrm{Al}$ in this case is soil.

Fig.4(f) shows that the concentrations of Fe and $\mathrm{Cu}$ are the maximum values at the beginning of the rain event and they decrease at the end. This tendency is very similar to $\mathrm{NO}_{3}{ }^{-}$, nss- $\mathrm{SO}_{4}{ }^{2-}$, and $\mathrm{NH}_{4}{ }^{+}$of the ASI group. The concentrations of Mn in Fig.4(f) also show the highest value at the beginning and then decrease down to almost non existence level in several hours. The tendency of $\mathrm{Mn}$ is very similar to $\mathrm{F}^{-}$in Fig.4(d). According to Mizohata \& Mamuro ${ }^{15)}$, the main source of Fe is soil and iron and steel industry; that of $\mathrm{Cu}$ is iron and steel industry and refuse incineration; that of $\mathrm{Mn}$ is the iron and steel industry. The main source of $\mathrm{NO}_{3}{ }^{-}$, nss- $\mathrm{SO}_{4}{ }^{2-}, \mathrm{NH}_{4}{ }^{+}$, and $\mathrm{F}^{-}$is anthropogenic pollution. Thus, it is thought that the main source of $\mathrm{Fe}$, and $\mathrm{Cu}$, and $\mathrm{Mn}$ in this case is anthropogenic pollution.

Fig.4(g) shows the concentrations of $\mathrm{Pb}, \mathrm{Ni}$, and $\mathrm{Zn}$. The concentrations tend to decrease to the lowest values at 2 hours after the beginning, and then increase up to the maximum values at 6 hours. At the end of the rain event, they are almost the same values at the beginning. According to Mizohata \& Mamuro $^{15)}$, the main source of $\mathrm{Pb}$ and $\mathrm{Zn}$ is the iron and steel industry and refuse incineration, and that of $\mathrm{Ni}$ is the iron and steel industry. Thus, it is thought that the main source of $\mathrm{Pb}, \mathrm{Ni}$, and $\mathrm{Zn}$ is anthropogenic pollution.

Fig.4(h) shows almost no variations in $\mathrm{Cd}$ and $\mathrm{Cr}$ concentrations. It can be inferred that these trace metals are barely contained.

\section{(5) Effect of total precipitation amount on con- centrations}

All coefficients for the precipitation amount and concentrations were negative. The concentration tended to decrease with higher precipitation amounts. This was regarded as the effect of "wash-out" and dilution reported from an earlier study ${ }^{49)}$. If a solute of an ion constituent is constant, then its concentration is reduced by the amount of a solvent of rainwater. The relation is discussed separately for the rainwater of rain events and the fractionally sampled rainwater in the following.

\section{a) Rainwater of rain events}

The relation and correlation coefficient between the precipitation amount and the concentration of SSI group are presented in Fig.5(a). No correlation was significant, but all coefficients were negative. The concentrations tended to increase with lower precipitation amounts.

For precipitation of $0-45 \mathrm{~mm}$, the concentrations decreased. This tendency was designated as "wash-out". When the precipitation amount was as high as $5 \mathrm{~mm}$, the results suggested that the concentration was high because the components in the atmosphere were being washed out. Then the concentration was diluted by rainwater.

For precipitation of 50-59 mm, the concentration turned to increase. The maximum instantaneous wind velocity of $19.2 \mathrm{~m} / \mathrm{s}^{34)}$ was observed at the rain event of M19. It was inferred that the advection by the strong wind raised the concentrations of the SSI group a little.

Many rain events with large amounts of precipitation tend to be related to strong winds. The relation between the concentrations of the SSI Group and 
M19, Maximum instantaneous wind velocity: $19.2 \mathrm{~m} / \mathrm{s}^{34)}$

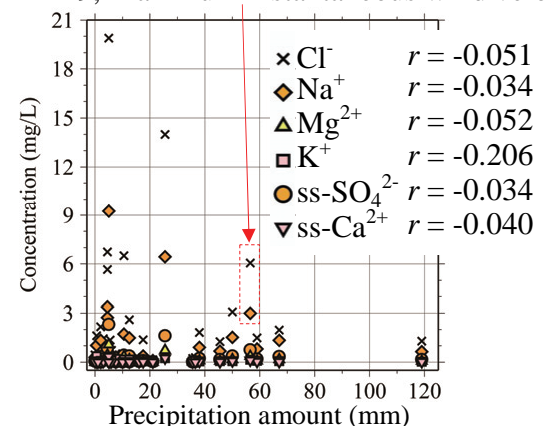

(a) Ions (SSI group) of rainwater of rain event

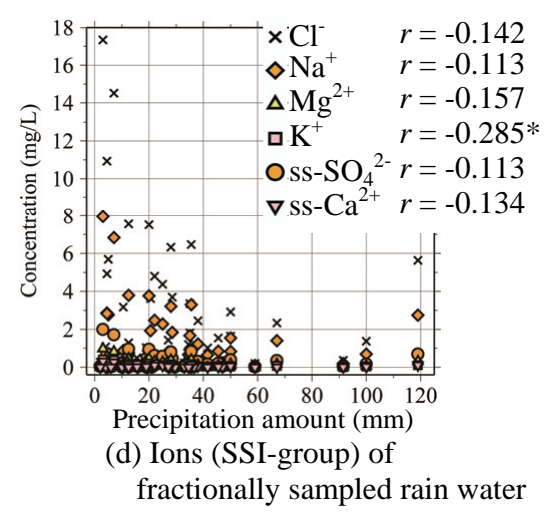

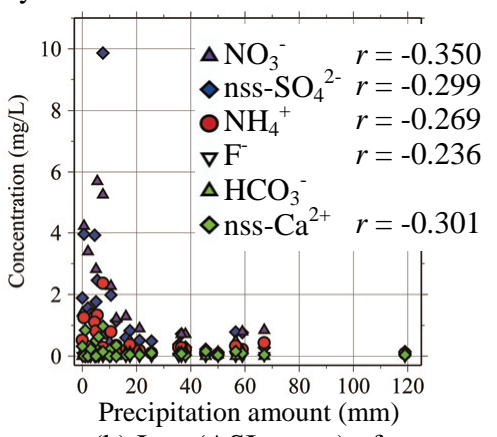

(b) Ions (ASI group) of rainwater of rain event

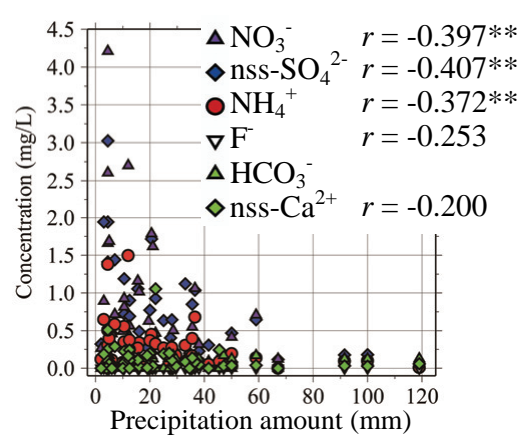

(e) Ions (ASI group) of

fractionally sampled rain water

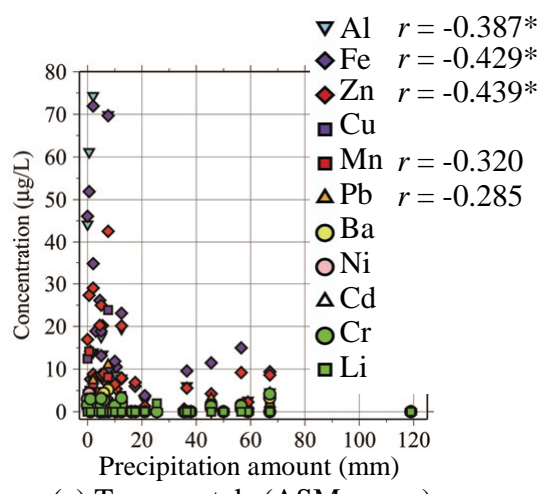

(c) Trace metals (ASM group) of rainwater of rain event

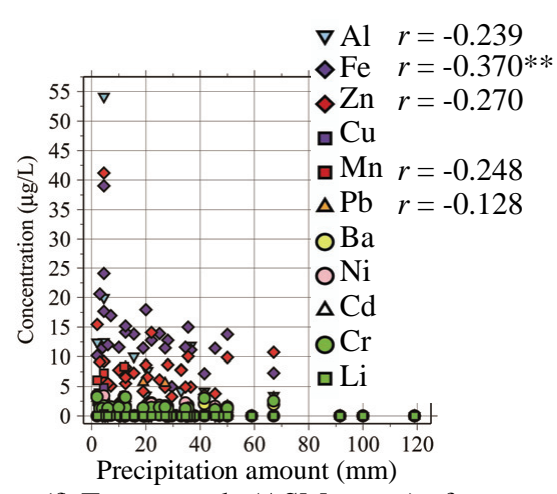

(f) Trace metals (ASM group) of fractionally sampled rain water

Fig.5 Relationship between precipitation amount and concentrations of rainwater. ${ }^{*} p<0.05$; ${ }^{* *} p<0.01$.

wind velocity is discussed in Section (6).

However, when the precipitation amount exceeded $60 \mathrm{~mm}$, our obtained concentrations tended to decrease to a certain value, which differed from earlier reported tendencies ${ }^{40)}$, suggesting a dilution effect of the rainwater.

The relations and correlation coefficients between the precipitation amounts and the ASI group concentrations are presented in Fig.5(b). No significant correlation was observed, but all coefficients were negative. The concentrations were regarded as tending to decrease with higher precipitation amounts.

When the precipitation amount was $0-25 \mathrm{~mm}$, the concentrations dropped rapidly in the U curve shape. Then, for precipitation amounts greater than $25 \mathrm{~mm}$, they tended to settle to nearly constant values. When the precipitation amount was around $60 \mathrm{~mm}$, the concentrations increased slightly. With precipitation of around $120 \mathrm{~mm}$, the concentrations decreased near the measurable limits.

The relation and correlation coefficients between the precipitation amount and the concentration of ASM group are presented in Fig.5(c). The correlations of $\mathrm{Al}, \mathrm{Fe}$, and $\mathrm{Zn}$ were weakly negative $(r=$ -0.439 to $-0.387, p<0.05$ ). The correlation of each of $\mathrm{Mn}$ and $\mathrm{Pb}$ was not significant but the coefficients were negative. A tendency was apparent by which the concentrations of the ASM group decreased with higher precipitation amounts. When the precipitation amount increased from 0 to $30 \mathrm{~mm}$, the concentrations decreased. Then, with precipitation of 30-60 $\mathrm{mm}$, the concentrations increased. Above $60 \mathrm{~mm}$, the concentrations began to decrease again. Around 120 $\mathrm{mm}$, the concentrations fell below the measurable limits.

\section{b) Fractionally sampled rainwater}

All the concentrations tended to decrease with the increase of the precipitation amount as described in an earlier report ${ }^{40)}$.

The relation and the correlation coefficients between the concentrations of SSI group and the precipitation amount are presented in Fig.5(d). The correlation of $\mathrm{K}^{+}$was weak and negative $(r=-0.285$, $p<0.05)$. Furthermore, no other correlation was significant, but all coefficients were negative. The SSI group concentrations were regarded as decreasing with higher precipitation amounts. Up to $90 \mathrm{~mm}$, the concentrations tended to decrease. At $100 \mathrm{~mm}$ and $120 \mathrm{~mm}$, the concentration began to increase. Because these events were typhoons with strong winds, results suggest that the wind velocity affected more than the precipitation amount in these cases.

The relation and correlation coefficients between the concentrations of ASI group and the precipitation amount are presented in Fig.5(e). Fig.5(f) presents 


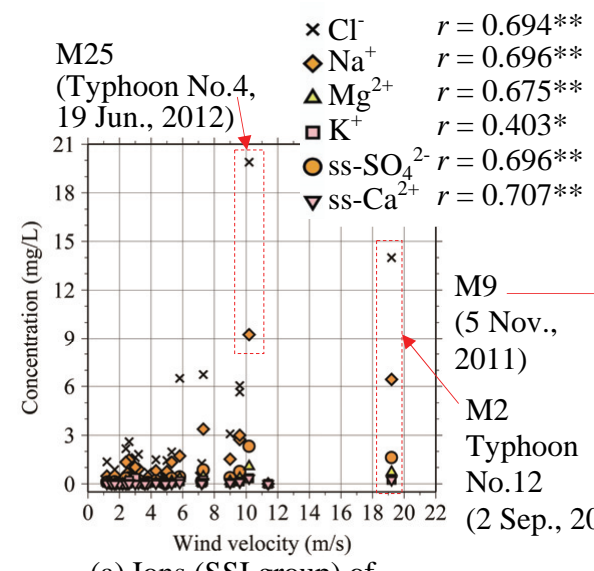

(a) Ions (SSI group) of

rainwater of rain event

Initial precipitation of M19

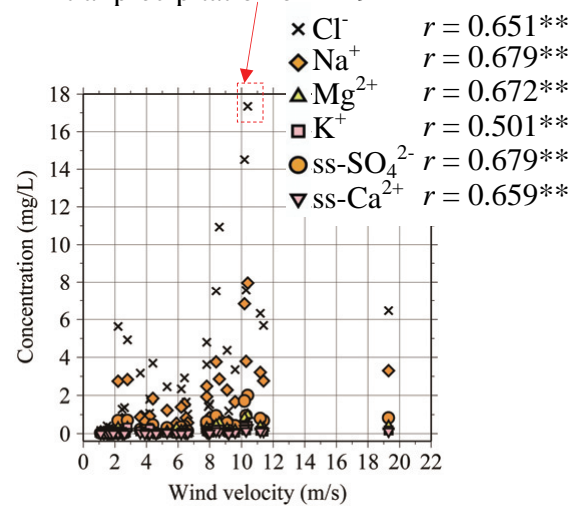

(d) Ions (SSI group) of

fractionally sampled rainwater

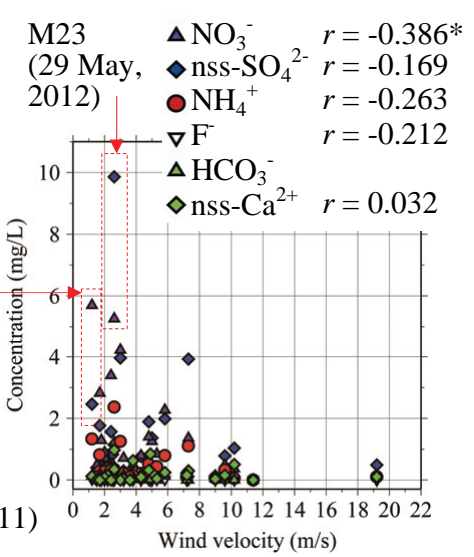

(b) Ions (ASI group) of

rainwater of rain event

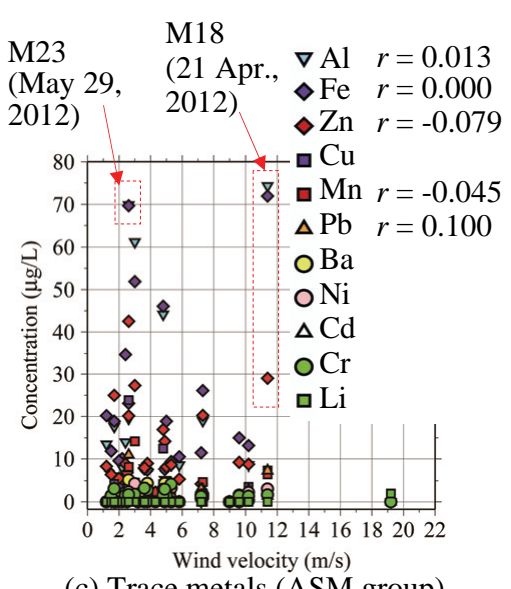

(c) Trace metals (ASM group) of rainwater of rain event

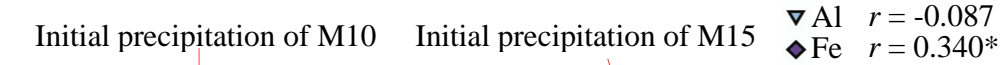

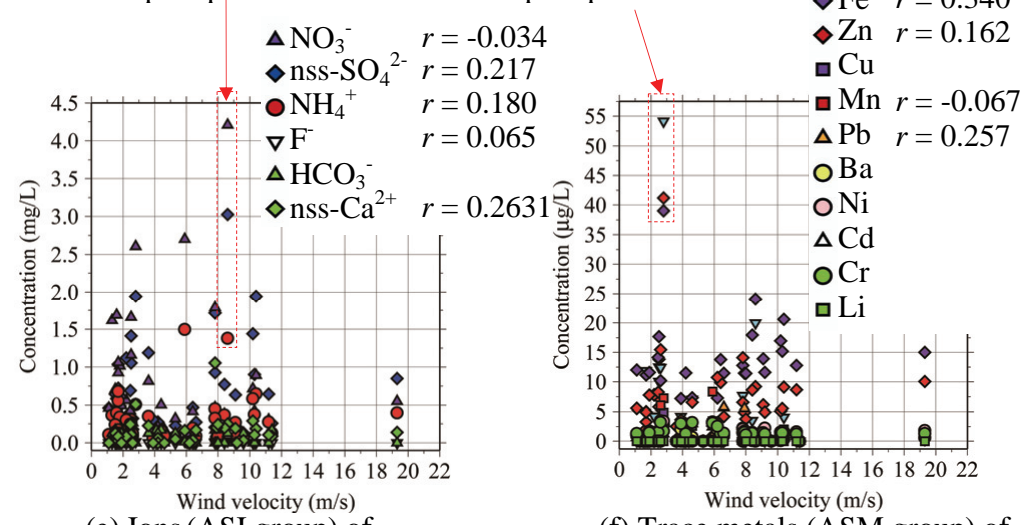

(e) Ions (ASI group) of

fractionally sampled rainwater

(f) Trace metals (ASM group) of fractionally sampled rainwater

Fig.6 Relationship between wind velocity and concentrations of rainwater. * $p<0.05$; ** $p<0.01$.

the results for the ASM group. $\mathrm{NO}_{3}^{-}, \mathrm{NH}_{4}{ }^{+}$, and nss- $\mathrm{SO}_{4}{ }^{2-}$ of ASI group, and $\mathrm{Fe}$ of ASM group exhibited weakly negative correlation $(r=-0.407$ to -0.370, $p<0.01$ ). Correlation of the other elements was negative but not significant. The concentrations of both groups tended to decrease with higher precipitation amounts.

\section{(6) Effect of wind velocity on rain concentrations}

The effects of wind velocity on concentrations are discussed in the rainwater of rain event and fractionally sampled rainwater.

\section{a) Rainwater of rain events}

The relation and the correlation coefficient between the wind velocity and the concentration of the SSI group are shown in Fig.6(a).

Correlations of $\mathrm{Cl}^{-}, \mathrm{Na}^{+}, \mathrm{Mg}^{2+}$, and $\mathrm{ss}_{-} \mathrm{SO}_{4}{ }^{2-}$ were highly positive $(r=0.675-0.707, p<0.01)$. The correlation of $\mathrm{K}^{+}$was weak and positive $(r=0.403$, $p<0.05)$. The concentration of SSI group tended to increase with higher wind velocity.

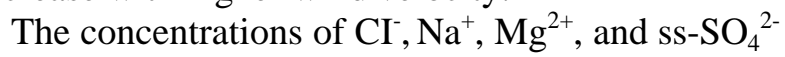
were the highest at $10.2 \mathrm{~m} / \mathrm{s}$ in the rain event of M25 (Typhoon No. 4, 2012). An earlier report ${ }^{39)}$ described that $\mathrm{Cl}^{-}$increases concomitantly with the wind velocity. At higher wind velocities, more seawater is raised and dispersed. Ions from sea salts are transported into the atmosphere. Then their concentrations in the rainwater are regarded as increased.

The relation and the correlation coefficient between the wind velocity and the ASI group concentration are depicted in Fig.6(b). The ASI group concentrations tended to decrease except nss- $\mathrm{Ca}^{2+}$. The correlation of $\mathrm{NO}_{3}{ }^{-}$was weakly negative $(r=$ -0.386, $p<0.05$ ). The correlation coefficients of $\mathrm{F}^{-}$, $\mathrm{NH}^{4+}$, nss- $\mathrm{SO}_{4}{ }^{2-}$ were negative but not significant. No correlation of nss-Ca ${ }^{2+}$ was found. The nss- $-\mathrm{SO}_{4}{ }^{2-}$ and $\mathrm{NO}_{3}{ }^{-}$were, respectively, the highest at M23 (29 May 2011) and at M9 (5 November 2011).

The relation and the correlation coefficient between the wind velocity and the ASM group concentrations are depicted in Fig.6(c). Concentrations of trace metals reportedly show negative correlation with wind velocity, similar to the correlations between aerosol concentrations and wind velocity ${ }^{53)-56)}$. Nevertheless, in this study, the trace metals except $\mathrm{Al}, \mathrm{Fe}$, and $\mathrm{Li}$ showed a tendency to increase with smaller wind velocity overall. Regarding $\mathrm{Al}$ and $\mathrm{Fe}$, 
the concentrations were the highest at M18 (Sample No. 18) in which the wind velocity was $11.4 \mathrm{~m} / \mathrm{s}$ and the precipitation amount was $2.0 \mathrm{~mm}$. Reportedly, the source of $\mathrm{Al}$ is soil, and that of $\mathrm{Fe}$ is the iron and steel industry and soil ${ }^{6)}$. They are contained much in deposition on the road ${ }^{57), 58)}$. Therefore, for Sample No. M18, results suggest that they were swirled up into the atmosphere and diffused by the strong wind. For the case in which the wind velocity was $19.2 \mathrm{~m} / \mathrm{s}$ in the rain event of Sample No. M2, the concentrations of all the trace metals except Li were below the measureable limits. Results suggest that they were diluted by the precipitation amount of $25.5 \mathrm{~mm}$.

\section{b) Fractionally sampled rainwater}

The relation and the correlation coefficient between the wind velocity and the concentration of SSI group are depicted in Fig.6(d). All the correlations were positive $(r=0.501-0.679, p<0.01)$. The concentrations increased with higher wind velocity when the reference wind velocity was set as $0.1 \mathrm{~m} / \mathrm{s}$. The increase in the wind velocity affected the increase in the concentrations, as reported earlier ${ }^{49)}$, and as shown in the results of respective rain events (Fig.6(a)).

The relation and the correlation coefficient between the wind velocity and the concentration of ASI group are depicted in Fig.6(e). No significant correlation was found. The concentrations of $\mathrm{NO}_{3}{ }^{-}$and nss- $\mathrm{SO}_{4}{ }^{2-}$ were the highest at $8.6 \mathrm{~m} / \mathrm{s}$. These data were obtained at the initial precipitation of Sample No. M10. The initial precipitation was regarded as bringing high concentration. The effect of the wind velocity on the increase in the concentrations was not recognized clearly.

The relation and the correlation coefficient between the wind velocity and the concentration of ASM group are depicted in Fig.6(f). The correlation of Fe was weakly positive $(r=0.340, p<0.05)$; $\mathrm{Fe}$ tended to increase with higher wind velocity. However, no correlation was found for any other element. The concentrations of $\mathrm{Al}, \mathrm{Zn}$, and Fe were the highest at $2.5 \mathrm{~m} / \mathrm{s}$ when the reference wind velocity was set as $0.1 \mathrm{~m} / \mathrm{s}$. These data were obtained from the initial precipitation of Sample No. M15. The high concentration was regarded as attributable to the initial precipitation.

\section{(7) Effect of wind direction on concentrations}

The effects of the wind direction on the concentration are discussed in the rainwater of rain event and the fractionally sampled rainwater.

\section{a) Rainwater of a rain event}

The relation between the wind direction and the concentration of SSI group are presented in Fig.7(a). The concentration increased at the wind directions of ESE and E. Table 6 shows that $\mathrm{Cl}^{-}, \mathrm{Na}^{+}, \mathrm{Mg}^{2+}$, and
Ss- $\mathrm{SO}_{4}{ }^{2-}$ showed weakly positive correlation with ESE $(r=0.357-0.390, p<0.05)$. The SSI group concentrations did not show significance, but showed positive correlation tendency with E. It was inferred that the atmosphere containing many sea salts was transported from the sea by winds of ESE and E.

The relation between the wind direction and the concentration of ASI group are presented in Fig.7(b). The concentrations were high at SE, ESE, W, and WNW. As shown in Table 6, $\mathrm{F}^{-}, \mathrm{NH}_{4}{ }^{+}$, nss- $\mathrm{SO}_{4}{ }^{2-}$ exhibited moderately positive correlation with SE $(r$ $=0.464-0.573, p<0.01)$. Nss- $-\mathrm{Ca}^{2+}$ showed weakly positive correlation with SE $(r=0.379, p<0.05)$. The wind from SE tended to increase the concentrations.

The relation between the wind direction and the concentration of ASM group are presented in Fig.7(c). The concentrations were high at ENE, ESE, $\mathrm{SE}, \mathrm{W}$, and NW. Table 6 shows that $\mathrm{Pb}$ had weakly positive correlation with SE $(r=0.463, p<0.05)$. The wind from SE tended to increase the $\mathrm{Pb}$ concentration. The effect of the wind direction on the ASM group concentrations was not as clear as that in the SSI group because the wind direction and the water quality were time-averaged in each rain event. Therefore, further discussion is presented in the following Section $\mathbf{b}$ ).

\section{b) Fractionally sampled rainwater}

The relation between the wind direction and the concentration of SSI group is presented in Fig.7(d). The concentration was greater for wind directions of $\mathrm{E}$ and ESE. Table 8 shows that all the elements exhibited moderately positive correlation with ESE ( $r=$ $0.413-0.582, p<0.01) . \mathrm{Cl}^{-}, \mathrm{Na}^{+}, \mathrm{Mg}^{2+}$, $\mathrm{ss}_{-} \mathrm{SO}_{4}{ }^{2-}$, and $\mathrm{ss}^{-\mathrm{Ca}^{2+}}$ had weakly positive correlation with $\mathrm{E}(r=$ $0.318-0.346, p<0.05) . \mathrm{K}^{+}$had weakly positive correlation $(r=0.359, p<0.05)$. The results were similar to the results obtained for the rain event in Fig.7(a).

The relation between the wind direction and the concentration of ASI group is presented in Fig.7(e). The concentrations tended to be high at NE, E, SE, and ESE. As shown in Table 8, $\mathrm{F}^{-}, \mathrm{NO}_{3}{ }^{-}$, nss- $\mathrm{SO}_{4}{ }^{2-}$, and nss- $\mathrm{Ca}^{2+}$ had weakly positive correlation with $\mathrm{NE}$ $(r=0.316-0.348, p<0.05)$. The nss- $\mathrm{Ca}^{2+}$ had weakly positive correlation with $\mathrm{E}(r=0.355, p<0.05)$.

The relation between the wind direction and the concentration of ASM group are presented in Fig.7(f). The concentrations were high at NE, E, and ESE. Table 8 shows that $\mathrm{Al}, \mathrm{Fe}, \mathrm{Mn}$, and $\mathrm{Zn}$ had highly positive correlation with NE $(r=0.541-$ $0.862, p<0.01)$. $\mathrm{Pb}$ had moderately positive correlation with ENE $(r=0.421, p<0.01)$. Regarding E, Fe showed moderately positive correlation $(r=0.439$, $p<0.01)$; $\mathrm{Pb}$ had weakly positive correlation $(r=$ $0.316, p<0.05$ ). The measured concentrations would be almost identical for all wind directions if the source was postulated to be distributed uniformly for 


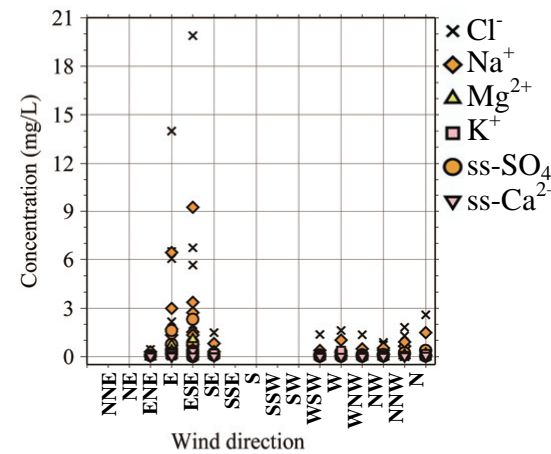

(a) Ions (SSI group) of rainwater of rain event

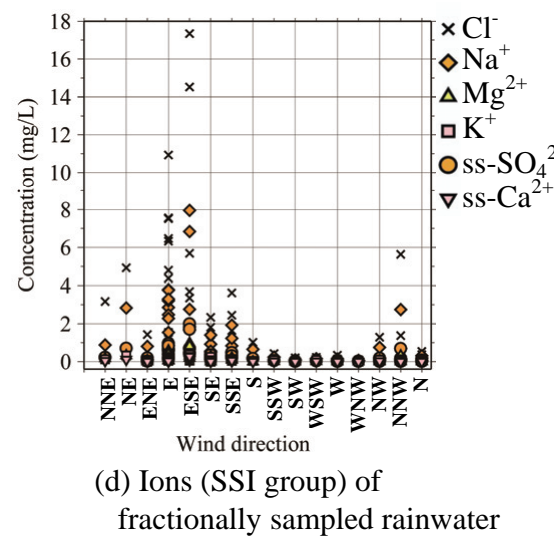

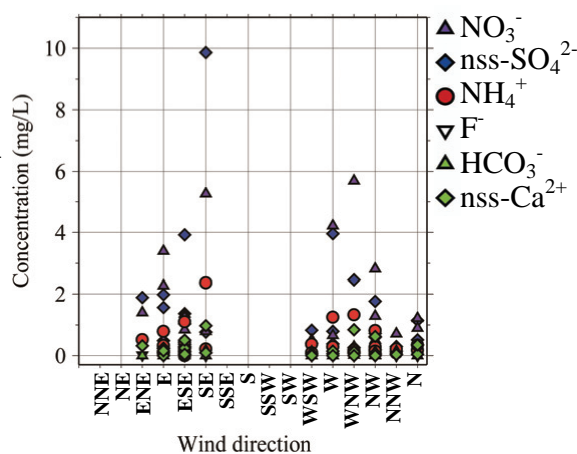

(b) Ions (ASI group) of rainwater of rain event

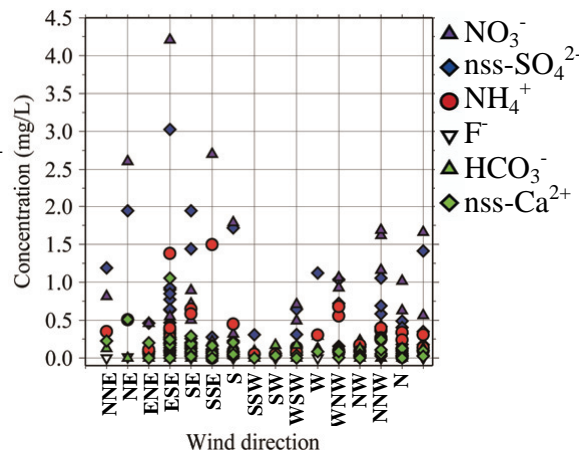

(e) Ions (ASI group) of fractionally sampled rainwater

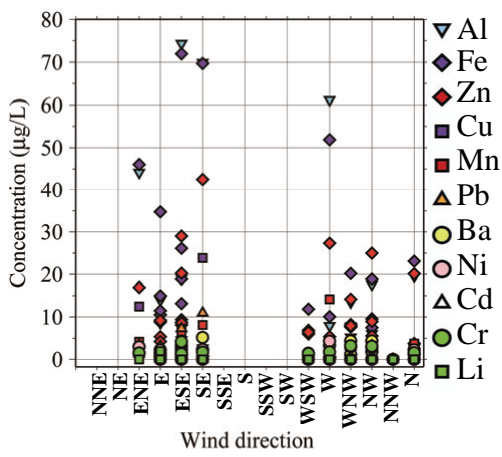

(c) Trace metals (ASM group) of rainwater of rain event

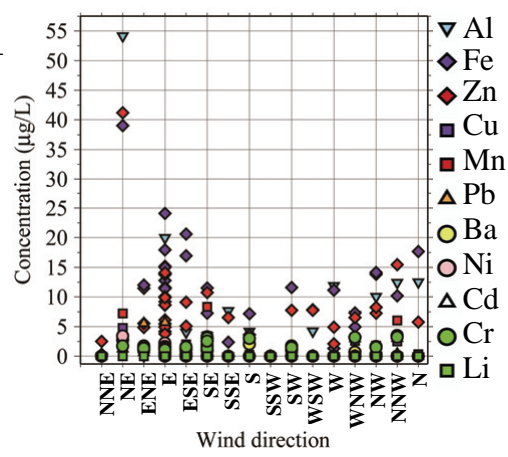

(f) Trace metals (ASM group) of fractionally sampled rainwater

Fig.7 Relationship between wind direction and concentrations of rainwater.

all directions. The high concentrations from NE and $E$ were high probably because of the effect of the pollutants from the industrial zone shown in Fig.1.

\section{(8) Principal component analysis}

To elucidate the overall effects of meteorological conditions and the effects of sources of elements, principal component analysis was performed on rainwater constituents and meteorological conditions using $R^{59)}$. Data were normalized for analyses.

\section{a) Rainwater of a rain event}

The analysis results are presented in Fig.8. The principal component score and the coefficients of the first and second principal component are presented in Fig.8(a) and Fig.8(b), respectively.

In the central part of Fig.8(a), the water quality was average. The rain events shown as distant from the central part such as Sample Nos. M23 and M25 showed that the water quality had characteristics shown by the principal component axis.

Sample No. M23 was from a rain event in which

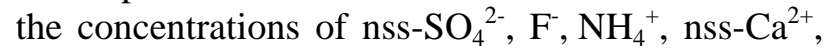
$\mathrm{Ba}, \mathrm{Ci}, \mathrm{Pb}$, and $\mathrm{Zn}$ were the highest. It was regarded as affected strongly by the anthropogenic pollution and soil.

Sample No. M25 was from a rain event in which the concentrations of $\mathrm{Cl}^{-}, \mathrm{ss}_{-} \mathrm{SO}_{4}{ }^{2-}, \mathrm{Na}^{+}, \mathrm{Mg}^{2+}$ and ss- $\mathrm{Ca}^{2+}$ were the highest. The wind was strong at 10.2 $\mathrm{m} / \mathrm{s}$ and the precipitation was $5 \mathrm{~mm}$. The event was regarded as affected strongly by sea salt.

In Fig.8(b), the rainwater constituents and the meteorological conditions were classified into three groups: Group (i), Group (ii), and Group (iii). Group (i) consisted of the SSI group and the meteorological conditions that raise their concentrations, which were the wind velocity and the wind direction ( $\mathrm{E}$ and ESE). Only $\mathrm{K}^{+}$in Group (i) was located near Group (ii). Results suggest that $\mathrm{K}^{+}$was transported not only by the local sea winds but also by air currents from continental Asia, as reported from an earlier study ${ }^{7}$. Group (ii) consisted of the ASI group, ASM group, and the meteorological conditions raising their concentrations, which was the wind direction (SE). Group (iii) included meteorological conditions that did not affect the concentrations of rainwater constituents.

\section{b) Fractionally sampled rainwater}

The results of these analyses are shown in Fig.9. The principal component score and coefficient are shown in Fig.9(a) and Fig.9(b), respectively.

Results clarified that the concentration tended to be higher during the initial period of the rain event and that meteorological conditions affected the increased concentration.

The rain events shown in the central part in Fig.9(a) show that the water quality is average. Blue triangle marks for precipitation occurring other than in the initial period of rain event are shown in the 


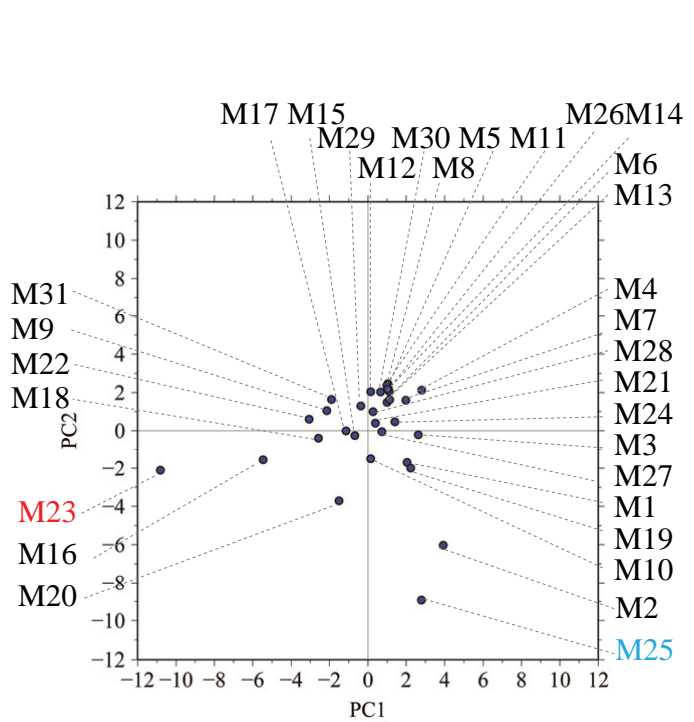

(a) Principal component score of rainwater of rain event

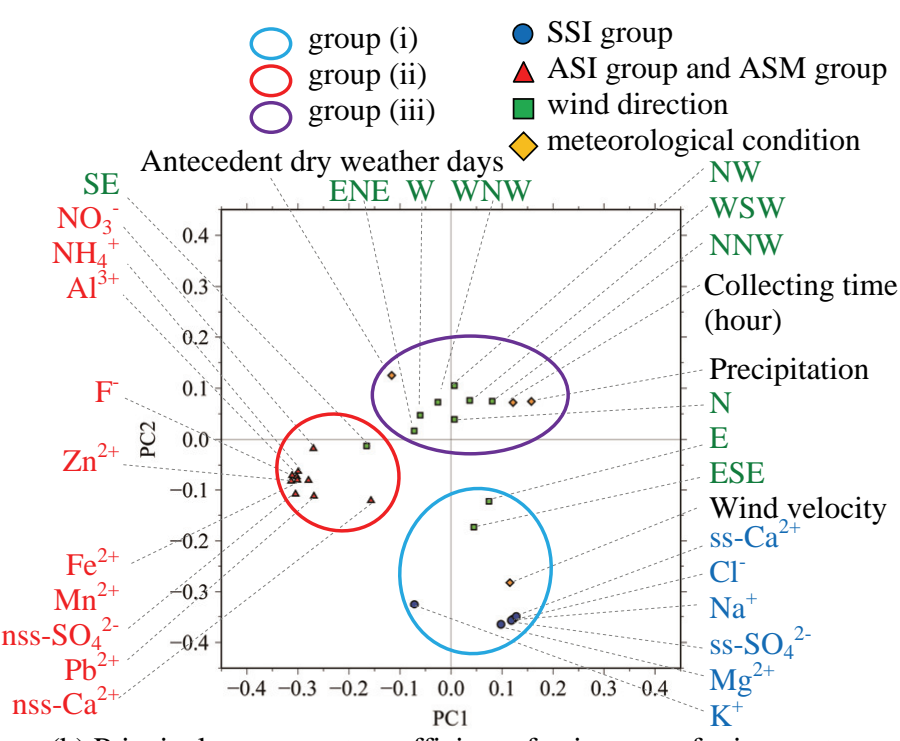

(b) Principal component coefficient of rainwater of rain event

Fig.8 Result of principal component analysis of rainwater of rain event. Group (i) consisted of SSI group and the meteorological conditions to raise their concentrations; i.e., the wind velocity and the wind direction (E and ESE). Group (ii) consisted of the ASI group, ASM group and the meteorological conditions that raise their concentrations, such as the wind direction (SE). Group (iii) included the meteorological conditions that did not affect the concentrations of rainwater constituents.

precipitation in initial period of rain event $\Delta$ precipitation other than in initial period M15 M27

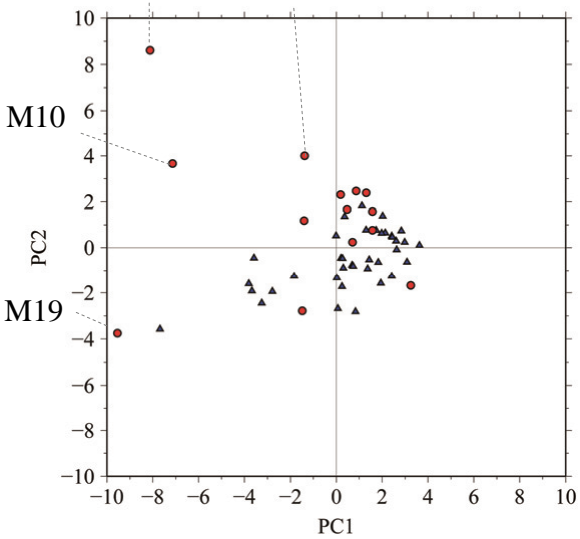

(a) Principal component score of fractionally sampled rainwater

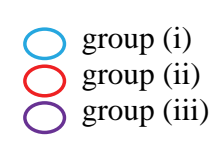
$\begin{array}{ll}\diamond & \text { meteorological condition } \\ \text { nss- } \mathrm{SO}_{4}{ }^{2-} \mathrm{NH}_{4}{ }^{+} \mathrm{Zn}^{2+} \mathrm{Al}^{3+} \mathrm{NO}_{3}^{-} & \text {Antecedent dry weather days }\end{array}$

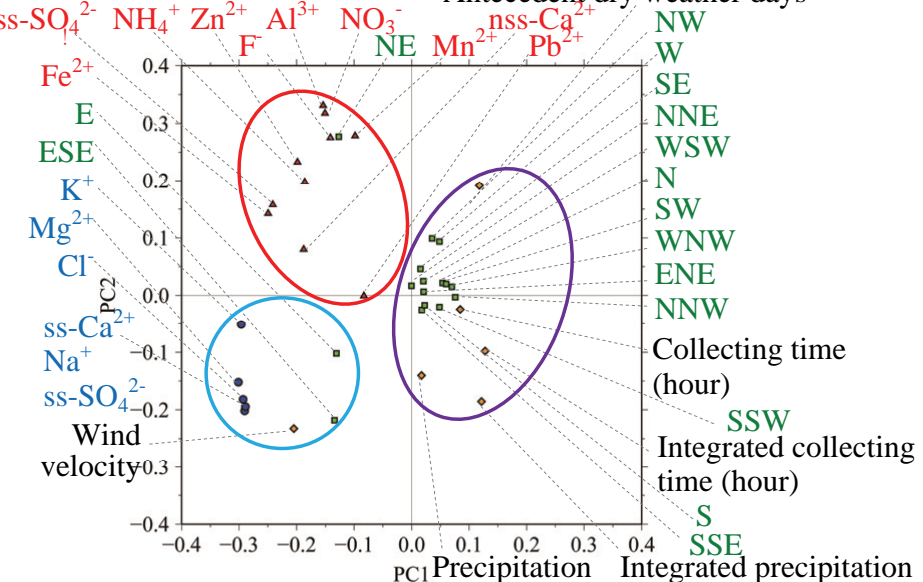

(b) Principal component coefficient of fractionally sampled rainwater

Fig.9 Result of principal component analysis of fractionally sampled rainwater. Group (i) consisted of SSI group and the meteorological conditions to raise their concentrations; i.e., the wind velocity and the wind direction (E and ESE). Group (ii) consisted of the ASI group, ASM group and the meteorological conditions that raise their concentrations, such as the wind direction (NE). Group (iii) included the meteorological conditions that did not affect the concentrations of rainwater constituents.

Table 9 Summary of the rain events with more than three highest concentrations in the initial period.

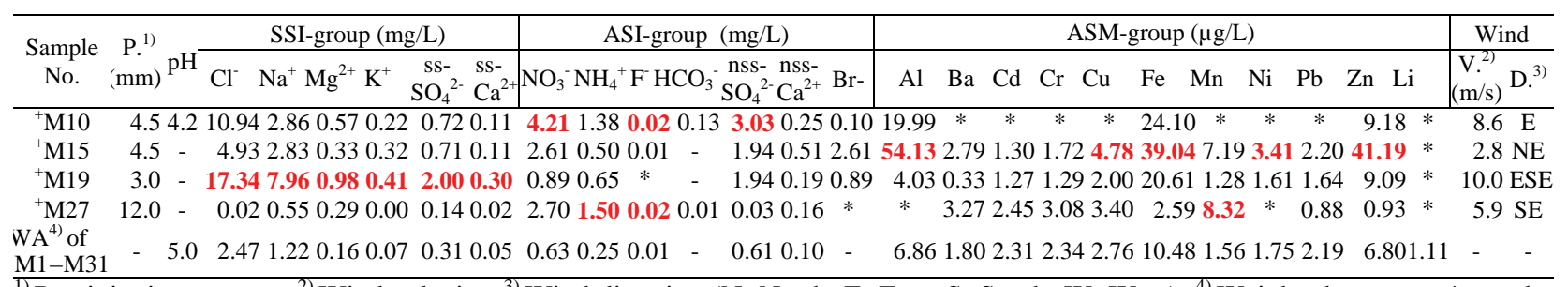

${ }^{1)}$ Precipitation amount; ${ }^{2)}$ Wind velocity; ${ }^{3)}$ Wind direction (N: North; E: East; S: South; W: West); ${ }^{4)}$ Weighted average; $*$ not detected; - missing value; ${ }^{+}$: sample collected every hours (1-several hours); Bold: Maximum value. 
central part. Red circle marks for the precipitation in the initial period of rain event are shown as distant from the central part. Their water quality is shown to have principal component characteristics. The water quality in the initial period of rain event is not of average but high concentration. In the rain in Mie prefecture $^{47)}$, for all constituents of the rainwater, it was observed that the incipient rainfall concentration, especially the first collected $1 \mathrm{~mm}$, was remarkably higher than the subsequently collected rainwater, and that the concentration tended to decrease with the increase of the precipitation amount.

Table 9 presents the sample numbers of rain events that had more than three highest concentrations during the initial period. Fig.9(a) shows that the initial precipitation of Sample Nos. M10, M15, M19, and M27 occur distant from the center. Their water quality is not average. However, their weighted average of rain events shows average water quality, as presented in Fig.8(a). It also indicates that the initial precipitation had the characteristic water quality.

In Fig.9(b), in the same manner as that shown in Fig.8(b), the constituents of the rainwater and the meteorological conditions are classified into three groups of Group (i), Group (ii), and Group (iii). Group (i) consists of the SSI group and the meteorological conditions to raise their concentrations, i.e., the wind velocity and the wind direction (E and ESE). Only $\mathrm{K}^{+}$in Group (i) is located near Group (ii). This is similar to the result in each rain event as presented in Fig.8(b). Group (ii) consists of the ASI group, ASM group and the meteorological condition to raise their concentrations, i.e., the wind direction (NE). Group (iii) is the meteorological condition, which does not affect the concentrations of rainwater constituents.

\section{(9) Correlation between $\mathrm{Pb}$ and acid concentra- tions}

Fig.10 shows that the correlation of the concentrations between $\mathrm{Pb}$ and acid components of nss- $\mathrm{SO}_{4}{ }^{2-}$ and $\mathrm{NO}_{3}{ }^{-}$at the rain events (M15-M31) in Tsu City are positive. The correlation coefficients are $0.871(p<0.01)$ and $0.657(p<0.01)$, respectively. The $\mathrm{Pb}$ concentration tends to be high in proportion to the acid component concentrations.

$\mathrm{Pb}$ is contained in great quantities in "aerosols of the refuse incineration", "aerosols of the iron-steel industry" and "exhaust gases from cars with gasoline engines"15). Pollution by combustion of leaded gasoline has already been improved through government regulation ${ }^{60), 61)}$. Sulfuric acid and nitric acid are generated when sulfur dioxide from the combustion of fossil fuels and nitrogen oxide from cars are oxidized. These acids become components in precipitation, constituting the main acid components.

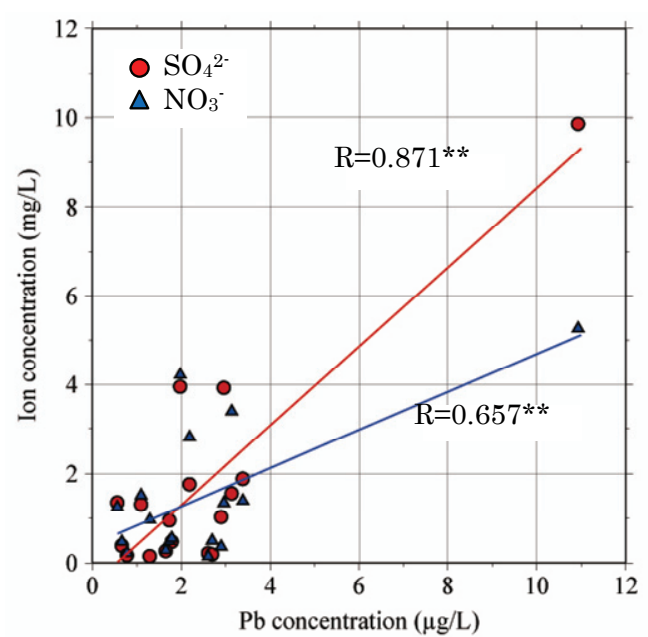

Fig.10 Correlation between $\mathrm{Pb}$ and acid concentrations. (Sample Nos. M15 $\cong$ M31). ${ }^{* *} p<0.01$.

Considering the generation processes of $\mathrm{Pb}$ and the acids and the proportionality of their concentrations in Tsu City, it is inferred that the local pollutants are transported to Tsu City by the atmosphere from the other areas where these pollutants exist.

\section{(10) $\mathrm{Pb} / \mathrm{Zn}$ ratio}

Fig.4(i) shows the temporal concentration ratio of $\mathrm{Pb}$ and $\mathrm{Zn}$ during 22-23 April 2012. The ratio in the precipitation was $0.06-0.18$.

Fig.11 presents the concentrations of $\mathrm{Pb}$ and $\mathrm{Zn}$ in rain events from August 2011 to December 2012. From August 2011 through January 2012, the Zn concentration was $0-8.3 \mu \mathrm{g} / \mathrm{L}$, whereas the $\mathrm{Pb}$ concentration was almost not detected. From April 2012 through June 2012, the $\mathrm{Zn}$ concentration was 4.1-42.5 $\mu \mathrm{g} / \mathrm{L}$, whereas the $\mathrm{Pb}$ concentration was 0.5-10.9 $\mu \mathrm{g} / \mathrm{L}$. From September 2012 through December 2012, the Zn concentration was 5.1-25.0 $\mu \mathrm{g} / \mathrm{L}$, whereas the $\mathrm{Pb}$ concentration was $0.2-2.7$ $\mu \mathrm{g} / \mathrm{L}$.

The $\mathrm{Zn}$ and $\mathrm{Pb}$ concentrations tended to be higher in spring than in autumn. The difference was assessed at a $1 \%$ significance level using a $t$-test of the difference of the two means. Observations in summer and winter were planned.

Fig.12 shows "the $\mathrm{Pb}$ and $\mathrm{Zn}$ ratios in the precipitations", "suspended particulate matter (SPM) con-

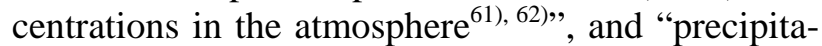
tion amounts" from April 2012 through December 2012. The reference data ${ }^{18), 20), 21)}$ of the $\mathrm{Pb}$ and $\mathrm{Zn}$ ratios are also plotted for the rain events when the parcel of air to bring rain moved through areas in Japan.

The SPM, of which the diameter is $10 \mu \mathrm{m}$ or less, is the index of air pollution. Some of them are generated artificially from such factors as combustion of fossil fuels, and others are produced naturally from such factors as soil. The SPM concentration tended to 


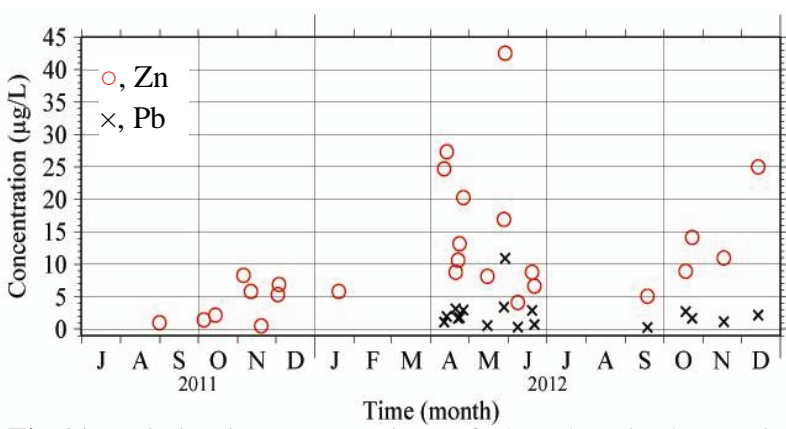

Fig.11 Variation in concentrations of $\mathrm{Pb}$ and $\mathrm{Zn}$ in the precipitations collected in Tsu City from August in 2011 to December in 2012. From August in 2011 through January in 2012, the concentration of $\mathrm{Pb}$ was not detected.

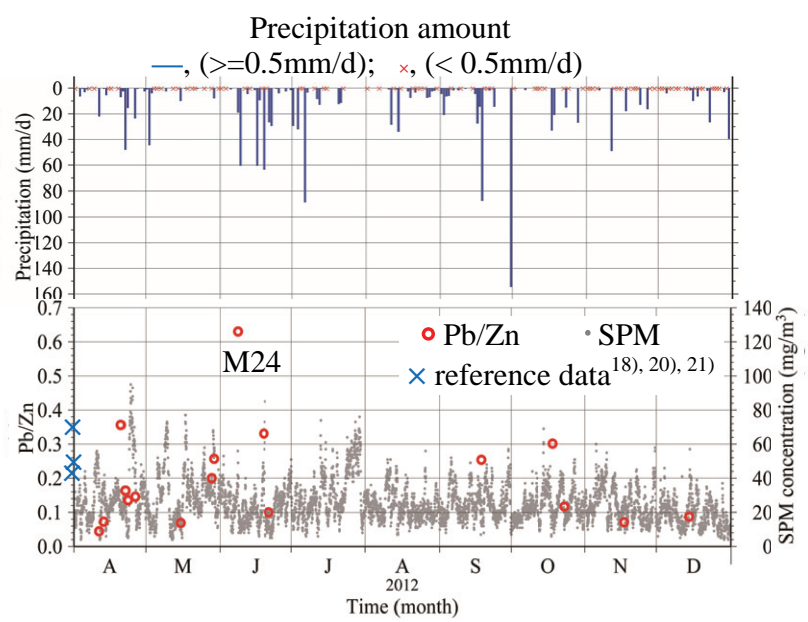

Fig.12 Variations of " $\mathrm{Pb} / \mathrm{Zn}$ ratios in the precipitations", "SPM (suspended particulate matter) concentrations

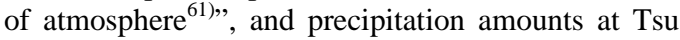
City from April to December in 2012.

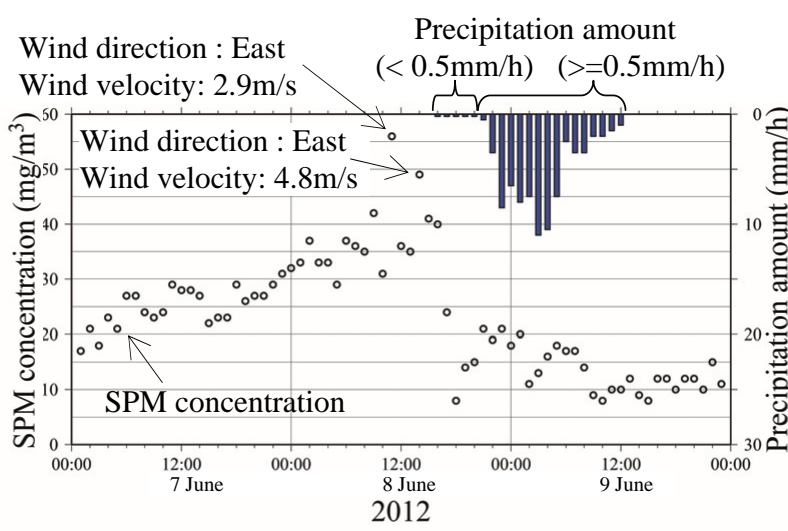

Fig.13 Variations in precipitation amounts, SPM concentrations, wind direction, and wind velocity.

decrease when the rain fell and it increased when the days without rain continued. The effect of "wash-out" was confirmed even with the precipitation amount less than $0.5 \mathrm{~mm} / \mathrm{d}$.

According to earlier studies ${ }^{18), 20), 21)}$, in the case of the long-range transport such as when a parcel of air to bring rain is transported from the continent, the ratio of $\mathrm{Pb}$ to $\mathrm{Zn}$ in the precipitation is greater than or equal to about 0.5 . For the 8-9 June 2012 rain event

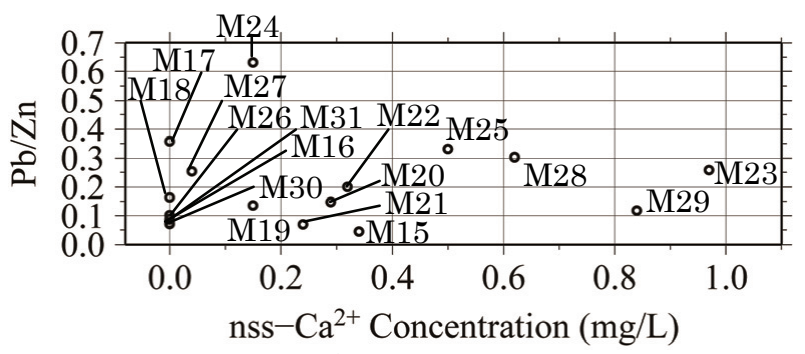

Fig.14 nss-Ca ${ }^{2+}$ concentration and $\mathrm{Pb} / \mathrm{Zn}$.

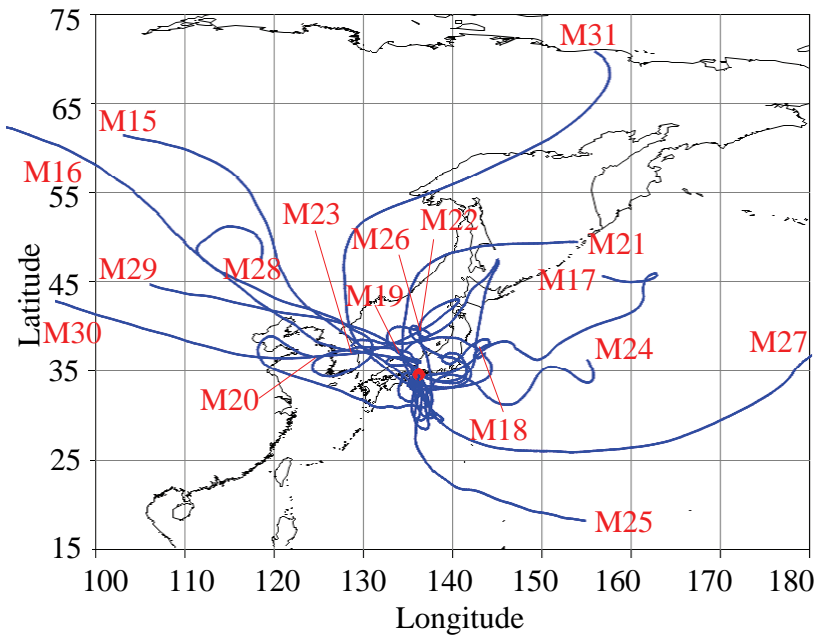

Fig.15 Isentropic backward trajectory analysis for Sample No. M15-M31.

Software: METEX (Meteorological Data Explorer); Trajectory length: 144 hour; Model: isentropic; reverses to 144 hours; Altitude reference: surface; Dataset: GPV; Altitude: 500m; Mode: Backward; Start point (red point): Tsu (Mie University).

(Sample No. M24), it was 0.63 in Fig.12.

Except for this high example of 0.63 , the other concentration ratios of $\mathrm{Pb} / \mathrm{Zn}$ were lower than 0.4 and within the reference data when the parcel of air to bring rain moved through areas in Japan.

Another study ${ }^{63)}$ found that the ratio at the ground surface was 0.25 . For soil raised aloft by strong winds, the ratio in the precipitation might be around 0.25 . Therefore, a comparison between obtained data other than 0.63 and the reference data above showed that the pollution in Tsu City was caused not by the pollutant transport from the continent but by the local pollutants and was regarded as local pollution.

The high $\mathrm{Pb} / \mathrm{Zn}$ ratio of 0.63 (Sample No. M24) was deemed caused by the pollutants transported from the industrial zone by the east wind that were washed out during the rain event. Details are discussed below.

Fig.13 shows the SPM concentration in the atmosphere and the precipitation amount before, at, and after the rain event of M24 (7-9 June 2012) in Tsu City. Before the rain event, the SPM concentration was $45 \mathrm{mg} / \mathrm{m}^{2}$ or more and the wind blew from the east. When it started to rain, the SPM concentration dropped sharply. Therefore, one of the causes for 
the high $\mathrm{Pb} / \mathrm{Zn}$ ratio was inferred as follows. The east wind would transport artificial pollutants to Tsu City from the industrial zone across Ise Bay as shown in Fig.1. Then the concentration of the pollutants in the atmosphere in Tsu City would increase and the pollutants would be washed out.

Fig.14 shows the relationship between the nss- $\mathrm{Ca}^{2+}$ concentration and the $\mathrm{Pb} / \mathrm{Zn}$ ratio. The nss- $\mathrm{Ca}^{2+}$ originates mainly from soil, and it is said that its concentration tends to increase when the kosa arrives. However, the nss-Ca ${ }^{2+}$ concentration of M24 was low.

Fig.15 shows the result of the isentropic backward trajectory analysis with the trajectory length of 144 hours and the altitude of $500 \mathrm{~m}$. The backward trajectory of M24 did not come from the Asian Continent. Therefore, it could not be inferred that the kosa caused the increase of the $\mathrm{Pb} / \mathrm{Zn}$ ratio of M24.

The backward trajectories of M17 and M25, of which the $\mathrm{Pb} / \mathrm{Zn}$ ratios were more than 0.3 , did not come from the Asian Continent, either. The backward trajectories of M15, M16, M29, and M30 came from the Asian Continent, but their $\mathrm{Pb} / \mathrm{Zn}$ ratios were low.

From the above discussion, the high $\mathrm{Pb} / \mathrm{Zn}$ ratio of 0.63 (Sample No. M24) could have been caused by the pollutants transported from the industrial zone by the east wind.

\section{CONCLUSION}

The main conclusions are as follows:

1) The main ion concentrations in the rainwater of each rain event in Tsu City were not different from the national average.

2) From analyses of the obtained correlation coefficients and results of principal component analyses, the ions and trace metals in the rainwater were classified into the SSI group, ASI group, or ASM group.

SSI group: $\mathrm{Cl}^{-}, \mathrm{Na}^{+}, \mathrm{K}^{+}, \mathrm{Mg}^{2+}$, $\mathrm{ss}_{-} \mathrm{SO}_{4}{ }^{2-}$, and $\mathrm{ss}-\mathrm{Ca}^{2+}$, the main sources of which are sea salt.

ASI group: $\mathrm{F}^{-}, \mathrm{NO}_{3}^{-}, \mathrm{NH}_{4}^{+}$, nss- $\mathrm{SO}_{4}{ }^{2-}$, and nss- $\mathrm{Ca}^{2+}$, the main sources of which are anthropogenic pollution and soil.

ASM group: $\mathrm{Al}, \mathrm{Fe}, \mathrm{Mn}, \mathrm{Pb}$, and $\mathrm{Zn}$ trace metals, the main sources of which are anthropogenic pollution and soil.

3) The results of hourly variations in concentrations showed the "wash-out" effect for all elements. The concentrations were high initially. They subsequently decreased to a certain level.

4) The concentrations tended to be lower with the increase in the precipitation amount in general, which is regarded as the dilution effect.

5) The SSI group concentrations tended to be higher with increased wind velocity in both the rainwater of rain event and the fractionally sampled rainwater. Results suggest that the seawater was raised aloft into the atmosphere in proportion to the wind velocity. Sea salt ions were transported and concentrated in the rainwater.

6) When the wind direction was ESE and E, the concentrations of SSI group tended to be higher in both the rainwater of the rain event and the fractionally sampled rainwater, probably because of winds from the sea to the east of Tsu City. When the wind direction was NE, the AS group and ASM group concentrations tended to increase in the fractionally sampled rainwater. It is regarded as influenced by anthropogenic pollution from the industrial zone located to the NE of Tsu City.

7) The rainwater in the initial period had high concentrations and a characteristic of its sources. After the initial period, the water quality became close to the average.

8) In 2012, the pollution in the precipitation in Tsu City was regarded as mainly composed of local pollutants.

9) Regarding the $\mathrm{Pb} / \mathrm{Zn}$ concentration ratio as an index of the transport of pollutants in Tsu City, it was recognized that the measured ratios were identical and within the reference data of rain events when air bringing rain moved through areas in Japan.

In this study, only one day in Tsu City showed a high $\mathrm{Pb} / \mathrm{Zn}$ concentration ratio. It was inferred that the strong east wind, with maximum instantaneous velocity of $19.2 \mathrm{~m} / \mathrm{s}$, would transport artificial pollutants to Tsu City from the industrial zone across Ise Bay.

ACKNOWLEDGMENT: This work was partly supported by research funds of Mie University. The authors are grateful to Dr. Kihira and Prof. Kato of the Iga Research Institute of Mie University for their help in the ICP analyses.

\section{REFERENCES}

1) Science Council of Japan: Global circulatory elucidation and influence measures of yellow sand and long distance crossing air pollution, 30pp, 2010 (in Japanese).

2) Kawamura, T.: Atmosphere Environment Theory, Asakura Publishing, Tokyo, 138pp, 1987 (in Japanese).

3) Likens, G. E. and Butler, T. J.: Recent acidification of precipitation in North America, Atmospheric Environment, Vol. 15, No. 7, pp. 1103-1109, 1981.

4) Ezcurra, A., Cassado, H., Lacaux, J. P. and Garcia, C.: Relationships between meteorological situation and acid rain in Spanish Basque country, Atmospheric Environment, 
Vol. 22, No. 12, pp. 2779-2786, 1988.

5) Schreurs, M. A., Welch, P. and Koda, A.: Japan: Elite newspaper reporting of the acid rain issue from 1972 to 1992, The press and global environmental change: An international comparison of elite newspaper reporting on the acid rain issue from 1972 to 1992, CSIA (the Center for Science and International Affairs) Discussion Paper, Vol. 95-12, pp. G1-G36, 1995.

6) Mizohata, A. and Mamuro, T.: Chemical element balances and identification of air pollution sources in Sakai, Osaka (I), Journal of Japan Society of Air Pollution, Vol. 15, No. 5, pp. 198-206, 1980 (in Japanese).

7) Ozeki, T., Ihara, T., Okada, T., Kikuchi, R. and Ogawa, N.: Monitoring of long-distance transportation of pollutants in precipitation in coastal areas facing the Japan Sea, Japan (2000-2001) and the grouping of ions in pollutants by principal component analysis, Bunseki Kagaku, Vol. 53, No. 12, pp. 1427-1434, 2004 (in Japanese).

8) Hioki, T., Nakanishi, S., Mukai, H. and Murano, K.: Analysis of long-range transported and local air pollution with trace metal concentration ratio and lead isotope ratio in precipitation, Journal of Japan Society for Atmospheric Environment / Taiki Kankyo Gakkaishi, Vol. 43, No. 2, pp. 100-111, 2008 (in Japanese).

9) Lacaux, J. P., Loemba-Ndembi, J., Lefeivre, B., Cros, B. and Delmas, R.: Biogenic emissions and biomass burning influences on the chemistry of the fogwater and stratiform precipitations in the African equatorial forest, Atmospheric Environment, Part A. General Topics, Vol. 26, No. 4, pp. 541-551, 1992.

10) Vautz, W., Schilling, M., Goncalves, F. L. T., Solci, M. C., Massambani, O. and Klockow, D.: Preliminary analysis of atmospheric scavenging processes in the industrial region of Cubatao, southeastern Brazil, Water, Air, and Soil Pollution, Vol. 85, No. 4, pp. 1973-1978, 1995.

11) Hioki, T., Kimoto, T., Hasegawa, S., Mukai, H., Ohara, T. and Wakamatsu, S.: Analysis of long-range transported and local air pollution with trace metal concentration ratio in aerosols collected at Matsuyama, Osaka and Tsukuba, Japan, Journal of Japan Society for Atmospheric Environment / Taiki Kankyo Gakkaishi, Vol. 44, No. 2, pp. 91-101, 2009 (in Japanese).

12) Okuda, T., Tenmoku, M., Kato, J., Mori, J., Sato, T., Yokochi, R. and Tanaka, S.: Long-term observation of trace metal concentration in aerosols at a remote island Rishiri, Japan by using inductively coupled plasma mass spectrometry equipped with laser ablation, Water, Air, and Soil Pollution, Vol. 174, pp. 3-17, 2006.

13) Furuta, N., Iijima, A., Kambe, A., Sakai, K. and Sato, K.: Concentrations, enrichment and predominant sources of $\mathrm{Sb}$ and other trace elements in size classified airborne particulate matter collected in Tokyo from 1995 to 2004, Journal of Environmental Monitoring, Vol. 7, pp. 1155-1161, 2005.

14) Marumoto, K., Sakata, M., Yoshimura, T. and Okumura, M.: Evaluation for emission sources of mercury in the air and precipitation - Effects of long-range transport from the Asian continent in a region facing the Sea of Japan -, CRIEPI (Central Research Institute of Electric Power Industry) Report, T00024, 2001 (in Japanese).

15) Mizohata, A. and Mamuro, T.: Chemical element balances and identification of air pollution sources in Sakai, Osaka (I), Journal of the Japan Society of Air Pollution / Taiki Osen Gakkaishi, Vol. 15, No. 5, pp. 198-206, 1980 (in Japanese).

16) Mukai, H., Ambe, Y., Shibata, K., Muku, T., Takeshita, K., Fukuma, T., Takahashi, J. and Mizota, S.: Long-term variations of chemical composition of atmospheric aerosol on the Oki Islands in the Sea of Japan, Atmospheric Environment, Vol. 24A, No. 6, pp. 1379-1390, 1990.
17) Mukai, H., Tanaka, A., Fujii, T. and Nakao, M.: Lead isotope ratios of airborne particulate matter as tracers of longrange transport of air pollutants around Japan, Journal of Geophysical Research: Atmospheres, Vol. 99, pp. 37173726, 1994.

18) Mukai, H., Tanaka, A. and Fujii, T.: Lead isotope ratios in snow collected in Japan and their relations to long-range transport of air pollutants, Journal of Japan Society for Atmospheric Environment / Taiki Kankyo Gakkaishi, Vol. 34, No. 2, pp. 86-102, 1999 (in Japanese).

19) Okuda, T., Kato, J., Mori, J., Tenmoku, M., Suda, Y., Tanaka, S., He, K., Ma, Y., Yang, F., Yu, X., Duan, F. and Lei, Y.: Daily concentrations of trace metals in aerosols in Beijing, China, determined by using inductively coupled plasma mass spectrometry equipped with laser ablation analysis, and source identification of aerosols, Science of the Total Environment, Vol. 330, pp. 145-158, 2004.

20) Sakata, M. and Marumoto, K.: Annual changes in wet deposition fluxes of trace metals and scavenging of mercury by precipitation in the Western Tokyo metropolitan area, Journal of Environmental Chemistry, Vol. 14, No. 3, pp. 555-565, 2004 (in Japanese).

21) Shimada, Y., Nakashima, A., Yamasaki, M. and Ikeda, Y.: Evaluation of long-range transport of air pollutants with ionic compounds and trace metals in initial precipitations collected in Fukuoka City, Annual Report of Fukuoka City Institute for Hygiene and Environment, Vol. 34, pp. 39-46, 2008 (in Japanese).

22) The Environmental Administration Bureau, Atmosphere Environment section (The Environmental Agency, The Air Quality Bureau, Atmosphere regulation section: Report on Analytical Results of Airborne Particulate Matter-National Air Surveillance Network, Japan), 254 pp, 1996 (in Japanese).

23) The Japan Iron and Steel Federation: Iron and Steel Statistics Handbook, The Japan Iron and Steel Federation, 306 p, 2013 (in Japanese).

24) Japan Automobile Manufacturers Association: The Motor Industry of Japan, Locations of Auto Manufacturing Plants, pp. 65, 2013, http://www.jama-english.jp/publications/ MIJ2013.pdf, Last access May 10, 2014.

25) Chubu Electric Power Co., Inc.: Annual Report 2013, pp. 3, 2013, http://www.chuden.co.jp/english/resource/ir/annual 13_2.pdf, Last access May 10, 2014.

26) Japan Petrochemical Industry Association: Geographical Locations of Petrochemical Complexes, http://www.jpca. or.jp/english/03petro_complex/index.htm, Last access May 10, 2014.

27) Mie prefectural government: The Environment of Mie Prefecture, http://www.eco.pref.mie.lg.jp/cycle/100160/ ipai2007/doc/2007-6-1a.pdf, Last access May 10, 2014 (in Japanese).

28) Aichi prefectural government: The secondary project of garbage incineration disposal in Aichi prefectural, pp. 6, 2009, http://kankyojoho.pref.aichi.jp/DownLoad/Down Load/kouikika_keikaku_no2.pdf, Last access May 10, 2014 (in Japanese).

29) Shiga prefectural government: The third plan of waste treatment, pp.7, 2011, http://www.pref.shiga.lg.jp/d/ haikibutsu/keikaku/files/keikakusankousiryou.pdf, Last access May 10, 2014 (in Japanese).

30) Nara prefectural government: pp.56-58, 2013, http://www. pref.nara.jp/secure/25836/shiryouhen.pdf, Last access May 10, 2014 (in Japanese).

31) Kyoto prefectural government: Map of refuse incineration facility, 2014, http://gomi-map.crap.jp/pk/26.html, Last access May 10, 2014 (in Japanese).

32) Japan Meteorological Agency, Ocean Observation Guide- 
line, 200 pp, 1999 (in Japanese).

33) Matsumoto, R., Yonemochi, S., Maruyama, Y., Kokubo, A. and Sakamoto, K.: Influence of Waste Incinerators on the Deposition Flux of Non-sea Salt Chloride Ion, Journal of Japan Society for Atmospheric Environment, Vol. 41, No. 3, pp. 135-143, 2006 (in Japanese).

34) Japan Meteorological Agency, AMeDAS (Automated Meteorological Data Acquisition System).

35) METEX (Meteorological Data Explorer), http://db.cger. nies.go.jp.

36) WMO (World Meteorological Organization): The Manual for the GAW Precipitation Chemistry Programme, Global Atmosphere Watch Report No. 160, WMO/TD-No. 1251, 2004.

37) Ministry of the Environment Government of Japan (2011) http://www.env.go.jp/air/acidrain/monitoring/h23/index. html (in Japanese).

38) Japan Weather Association: Manuals for Oceanographic Observation, pp. 145, 1978 (in Japanese).

39) Environmental Laboratories Association: $4^{\text {th }}$ investigation report of acid rain in Japan, Journal of Environmental Laboratories Association, Vol. 35, No. 2, pp. 58-135, 2005 (in Japanese).

40) Tang, A., Zhuang, G., Wang, Y., Yuan, H. and Sun, Y.: The chemistry of precipitation and its relation to aerosol in Beijing, Atmospheric Environment, Vol. 39, pp. 3397-3406, 2005.

41) Inoue, K., Zhang, Y. F., Itai, K., Tsunoda, H. and Zhao, J.: Influence of airborne particulate matters transported from the Asian continent on water-insoluble, soluble and gaseous Fluorine concentrations of aerosols in Japan, Japanese Journal of Soil Science and Plant Nutrition, Vol. 66, No. 3, pp. 223-232, 1995 (in Japanese).

42) Inoue, K., Hamaura, H., Xie, X., Itai, K. and Tsunoda, H.: Significant relationship between Fluoride and Sulfate or Calcium concentrations of rainwater in Japan, Japanese Journal of Soil Science and Plant Nutrition, Vol. 69, No. 5, pp. 457-462, 1998 (in Japanese).

43) Kawamura, S. and Hara, H.: Influence of Kosa on Precipitation Chemistry in Japan, Journal of Japan Society for Atmospheric Environment / Taiki Kankyo Gakkaishi, Vol. 41, No. 6, pp. 335-346, 2006 (in Japanese).

44) Inoue, K., Hamaura, H., Hiradate, S. and Kasai, O.: Influence of Asian long-range eolian dust on chemical components and inorganic dust deposits of rainwater in Northeast Japan, Japanese Journal of Soil Science and Plant Nutrition, Vol. 69, No. 5, pp. 445-456, 1998 (in Japanese).

45) Vautz, W., Busch, A. U., Urfer, W. and Klockow, D.: A statistical approach to estimate spatial distributions of wet deposition in Germany, Water, Air, and Soil Pollution, Vol. 145, pp. 215-238, 2003.

46) Takagi, N., Senda, M. and Kuzuha, Y.: Observational study on trace metals included in the precipitation, Proceedings of 2012 Annual Conference, Japan Society of Hydrology and Water Resources, Session ID: P18, 2012 (in Japanese).

47) Nishihara, T., Sarai, E., Tsukada, S. and Kawakami, M.: Acid Deposition Survey in Yokkaichi area of Mie Prefecture (2002 fiscal year), Annual Report of Mie Prefecture Health and Environment Research Institute, Vol. 5, pp. 116-125, 2003 (in Japanese).

48) Nakamura, K. and Mitani, M.: On the acid precipitation in the Shimousa district of the Boso Peninsula in Japan -A Discussion about the ion depositions in the district taking account of physical and chemical processes of the deposi- tion and the metrological conditions-, Tenki, pp. 1053-1063, 2012 (in Japanese).

49) Miyake, Y.: The chemistry of rain water, Journal of the Meteorological Society of Japan, II, Vol. 17, pp. 20-37, 1939 (in Japanese).

50) Durana, N., Casado, H., Ezcurra, A., Garcia, C., Lacaux, J. P. and Van Dinh, P.: Experimental study of the scavenging process by means of a sequential precipitation collector, preliminary results, Atmospheric Environment, Vol. 26A, No. 13, pp. 2437-2443, 1992.

51) Kurahashi, Y., Kawamura, R., Taniguchi, M. and Kawamura, T.: Temporal variations of chemical components in a rainfall at Tsukuba, Bulletin of Environmental Research Center, the University of Tsukuba, No. 14, pp. 37-48, 1990 (in Japanese).

52) Japan Meteorological Agency: Air pollutants, http://www. jma.go.jp/jma/kishou/know/yougo_hp/osen.html, Last access May 25, 2013 (in Japanese).

53) Charron, A. and Harrison, R. M.: Primary particle formation from vehicle emission during exhaust dilution in the roadside atmosphere, Atmospheric Environment, Vol. 37, pp. 4109-4119, 2003.

54) Hussein, T., Puustinen, A., Aalto, P. P., Makela, J. M, Hameri, K. and Kulmala, M.: Urban aerosol number size distributions, Atmospheric Chemistry and Physics, Vol. 4, pp. 391-411, 2004.

55) Hussein, T., Karpponen, A., Kukkonen, J., Aalto, P. P., Hameri, K., Kerminen, V-M. and Kulmala, M.: Meteorological dependence of size-fractionated number concentrations of urban aerosol particles, Atmospheric Environment, Vol. 40, No. 8, pp. 1427-1440, 2006.

56) Xia, L. and Gao, Y.: Characterization of trace elements in PM2.5 aerosols in the vicinity of highways in northeast New Jersey in the U.S. east coast, Atmospheric Pollution Research, Vol. 2, pp. 34-44, 2011.

57) Shinya, M., Tsuchinaga, T., Kitano, M., Yamada, Y. and Ishikawa, M.: Characterization of heavy metals and polycyclic aromatic hydrocarbons in urban highway runoff, Water Science and Technology, Vol. 42, Nos. 7-8, pp. 201-208, 2000.

58) Shinya, M., Tsuruho, K., Konishi, T. and Ishikawa, M.: Evaluation of factors influencing diffusion of pollutant loads in urban highway runoff, Water Science and Technology, Vol. 47 (7-8), pp. 227-232, 2003.

59) Ihaka, R. and Gentleman, R.: A language for data analysis and graphics, Journal of Computational and Graphical Statistics, Vol. 5, No. 3, pp. 299-314, 1996, http://www.R -project.org.

60) The Japan Petroleum Energy Center (JPEC): http://www. pecj.or.jp/japanese/report/reserch/report-pdf/H16_2004/04 cho2-2.pdf (in Japanese).

61) Department of Environmental and Social Affairs, Mie Prefecture, The atmospheric environmental data (in Japanese).

62) Nitta, H.: SPM, PM2.5, PM10, etc, Various particulate matters, National Institute for Environmental Studies, Vol. 20, No. 5, pp. 8-9, 2001 (in Japanese).

63) Rudnick, R. L. and Gao, S.: Composition of the continental crust, In The Crust (ed. Rudnick, R. L.) Vol.3 Treatise on Geochemistry (eds. Holland, H. D. and Turekion, K. K.), pp. 1-64, Elsevier Pergamon, Oxford, 2003.

(Received August 20, 2013) 